\title{
ANNUAL REPORT 1991
}

International Irrigation Management Institute 


\section{CONTENTS}

\section{FOREWORD}

\section{INTRODUCTION}

THEMATIC RESEARCH PROGRAMS 1

Performance Assessment $\quad 1$

Simulating Canal Operations 3

Farmer-Managed Irrigation Systems and Support Services 3

Privatization and Turnover $\quad 4$

Crop Diversification Network $\quad 5$

Health 6

Women and Irrigation 6

COUNTRY PROGRAMS

$\begin{array}{lr}\text { South and Southeast Asia } & 8\end{array}$

Sri Lanka $\quad 8$

$\begin{array}{lr}\text { The Philippines } & 10\end{array}$

Nepal $\quad 12$

India 13

Bangladesh 14

West Asia and Northeast Africa $\quad 16$

$\begin{array}{ll}\text { Pakistan } & 16\end{array}$

$\begin{array}{ll}\text { Sudan } \quad 18 & 18\end{array}$

$\begin{array}{ll}\text { Northwest and West Africa } & \mathbf{2 0}\end{array}$

$\begin{array}{ll}\text { Morocco } & 20\end{array}$

WEST AFRICA $\quad 21$

Burkina Faso $\quad 22$

Niger $\quad 23$

$\begin{array}{ll}\text { Nigeria } & 24\end{array}$

Latin America $\quad 25$

TRAINING AND CAPACITY BUILDING 26

Individual Training $\quad 27$

Collaborative Research Activities $\quad 27$

Workshops and Conferences $\quad 29$

INFORMATION

FINANCE AND ADMINISTRATTON 34

$\begin{array}{ll}\text { ANNEXES I - V } & 39-56\end{array}$

ACRONYMS AND SYMBOLS 57

$\begin{array}{ll}\text { IIMI ADDRESSES } & 58\end{array}$ 


\section{FOREWORD}

1991 was the Institute's first year as an active member of the Consultative Group for International Agricultural Research (CGIAR), and it brought with it new developments, partnerships and challenges that will have a significant bearing on IIMI's furure.

The year saw the successful conclusion of several important projects. The first phase of a five country program in Farmer-Managed Irrigation Systems was completed and the results shared with IIMI's global FMIS network, which now links 1,300 professionals in 75 countries. Work was also completed on a study to enhance the understanding of design and management interactions by linking results from research at two Malaysian irrigation systems. In the area of privatization and turnover, IIMI published a major discussion paper on Turnover and Self-Management of Irrigation Institutions in Developing Countries. The first stage of the Institute's innovative program to assess training needs and plan, design and develop irrigation management training curricula and materials reached a successful condusion in Malaysia.

During 1991, more and more countries turned to IIMI for insights into complex management questions or for research-based analysis and support. In Sri Lanka, several key policy papers written by IIMI staff on the basis of six years of field research are being used as the basis for policies that call for increased participation of farmers in the management of the country's irrigation systems. In Pakistan, senior staff of the Punjab irrigation sector met with IIMI staff during a two day "retreat" in October. Policymakers commented that they had gained valuable and unexpected insights from IIMI's research results. One immediate outcome of the retreat was the establishment of a committee to help IIMI to field test proposed management interventions in Punjab. In Sudan, IIMI was asked to sponsor a workshop on privatizing government irrigation schemes during which several far-reaching recommendations were made. During three weeks of mini-workshops in Bangladesh, senior management officials of the Bangladesh Agricultural Development Corporation brainstormed with IIMI colleagues on the Corporation's transition from a rubewell installing agency to one supporting the small-scale irrigation sector. And when a two-person IIMI team visited Latin America during 1991 to design the Institute's program for the region, many country representatives expressed strong interest in collaborating with IIMI.
Several new collaborative projects and agreements that offer exciting new opportunities were finalized during the year. In West Africa, IIMI joined the Burkina Faso office of the International Union for the Conservation of Nature in defining and implementing a program focused on irrigation and the environment. In Pakistan, the Institute has begun a major project to develop a crop-based irrigarion management system in the country's North West Frontier Province. A project on performance assessment implemented in collaboration with Hydraulics Research Ltd., of Wallingford, UK got off the ground in 1991, and IIMI's collaboration with the German Foundation for International Development continued throughout the year, with activities that ranged from a course on training of trainers in Malaysia in October to a workshop on adding a management orientation to irrigation engineering curricula in Bangkok in November.

The transition into the CGLAR system has required rethinking our straregy and developing workplans to fully capitalise on the opportunities that arise from membership in a worldwide network of international agricultural research centers. In December, the first draft of IIMI's revised strategy document was submitted to the Institute's Board. At the same time, IIMI initiated discussions with the CGIAR's 'Technical Advisory Committee to plan the first TAC External Program and Management Review of the Institute, now scheduled for early 1994.

The closing days of 1991 saw the Institute move to its new headquarters building. A gift from the host country, Sri Lanka, the new building provides the Institute with $80,000 \mathrm{sq}$. ft. of office space in a beautiful suburb of Colombo approximately 20 minutes from the commercial capital.

Despite IIMI's major accomplishments during 1991, several challenges remain. One is to adequately prepare for IIMI's new furure as a member of the CGIAR system, while maintaining the momentum of our current program and enhancing the quality and quantity of our research results. I look forward to reporting positively on this challenge in the 1992 Annual Report.

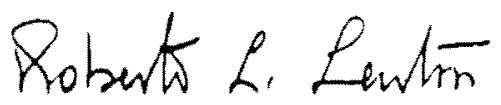

Roberto Lenton

Director General 


\section{Introduction}

This report presents details of the achievements of the International Irrigation Management Institute (IIMI) during 1991. The first section focuses on programs of thematic research carried out by the Institute in several developing countries. The second secrion describes IIMI's country

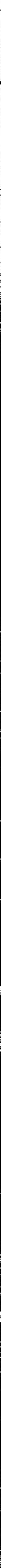




\section{Thematic Research Programs}

Since its founding in 1984, the International Irrigation Management Institute has worked to strengthen national efforts to improve and sustain the performance of irrigation systems in developing countries through the development and dissemination of management innovations. The key word is innovations: new ideas, operational methods, measurement tools, or management structures and arrangements that

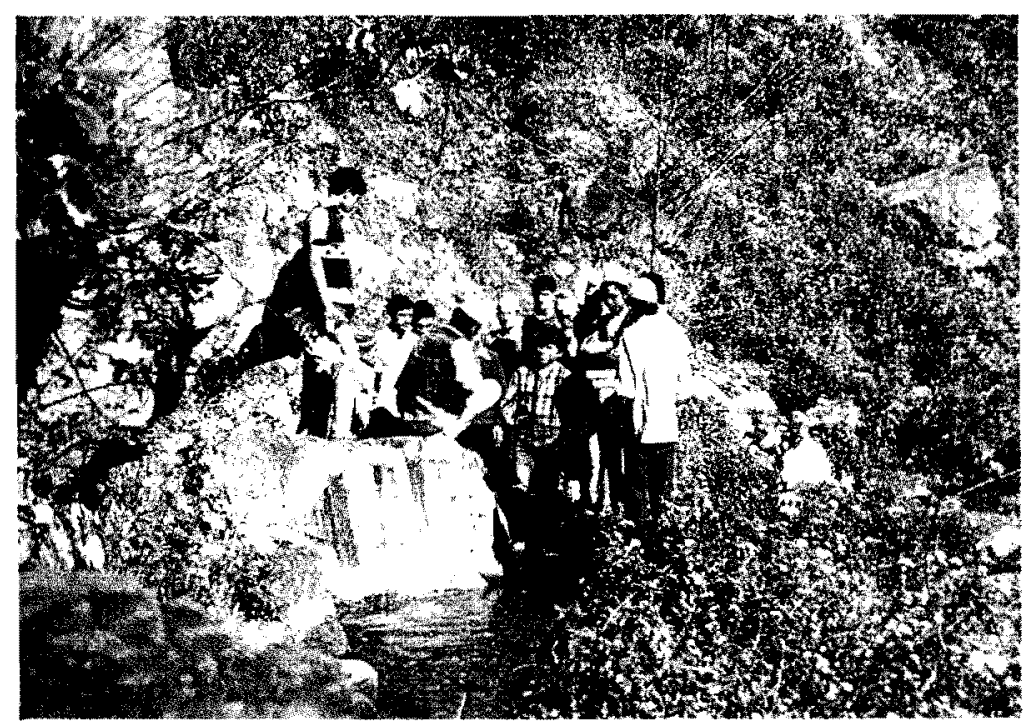

Farmer exchange visits are an effectine wechanisn for tranferring techologies and experience from one system to another.

bring about changes to improve the way an irrigation system performs. These changes may be completely novel. Or, they may represent the introduction of a practice which has been used successfully elsewhere, either in developed or developing countries.

IIMI looks for innovations in a variety of ways, through the Institute's own collaborative research in the specific locations, through the research of others, and through international newworks of scientists who exchange information in workshops and conferences and newsletters. Once a potential innovation is developed, a multidisciplined group of IIMI scientists based at headquarters discuss, review, evaluate, and systematically compare and apply it across a number of countries in a range of field conditions. The goal is new knowledge that is generic to irrigation systems from Indonesia to Nigeria.

For example, IIMI's scientists working in the farmer-managed hill irrigation systems of Nepal in 1986-87 noticed that some systems functioned better than others. So, they decided to bring a group of farmers from the superior systems to tour and visit farmers in the other systems. The result was farmer-to-farmer or peer training. Scientists then presented the idea at international workshops where it was discussed in a broader context. From there, IIMI fostered further discussion through the headquarters-based Farmer-Managed Irrigation Systems Newsletter. The notion of farmer-tofarmer training is now being successfully tested in IIMI field sites.

The results that follow represent advances made by IIMI scientists in generating innovations that can be generically applied in many countries.

\section{Performance Assessment}

In the 1980 s, IIMI gathered irrigation managers and planners to advise the Institute on priority issues for research. One word repeatedly surfaced in the discussions - performance. At the same time, in its early field work, IIMI scientists discovered they lacked certain critical information, like measurement of water deliveries, to compare and evaluate performance aspects of a given irrigation system.

For example, in 1987, in Indonesia, scientists and irrigation staff found why certain sections of a system were receiving too much water, while others were receiving too little - why planned deliveries did not match actual deliveries. As it 
turned out, the problem was not a case of imprecise information, but the absence of a simple system to properly record water deliveries in the field and then to use this data to monitor performance. Staff designed a special field book for use by gatekeepers. Once this was done, and accurate information started coming in, staff developed the "management performance ratio," a tool that allows managers to compare planned deliveries to actual deliveries on a regular basis.

In the broadest sense, assessing performance the effectiveness of an agency in achieving a set of objectives and the efficiency with which it marshals its resources to meet those needs - is present in all of IIMI's research. However, its importance both to the Institute's scientists and to its client collaborators, led IIMI in 1990 to select Performance Assessment as a research theme worthy of in-depth study.

In 1991, the Institute formed a Performance Task Force to develop a ten-year comprehensive program of research to address four aspects of performance in irrigation: performance indicators, methodologies for assessing performance, evaluating the determinants of performance, and institutional change and adoption of performanceoriented management. The Task Force is charged with the implementation of the Program and members will devote all their energies toward performance issues. However, other IIMI staff will participate on an intermittent basis in connection with associated project activities. By October, staff had completed an indepth work plan and had begun the initial four-year phase.

There were several early achievements related to the project. During the year staff completed a report on Performance Assessment Diagnosis, the first phase of a two-year collaborative project with the International Institute for Land Reclamation and Improvement and the International Institute for Hydraulic and Environmental Engineering, both based in the Netherlands. The project compared 15 case studies in Asia, Africa and Latin America, drawing parallels with elements of business management. This was used to develop hypotheses about design conditions that affect irrigation performance.

For example, systems that showed higher levels of efficiency were those with relatively simple objectives. This was particularly true where objectives represented a consensus between agencies and farmers, backed up by a clearly defined process for implementation, monitoring of actual conditions, feedback to decision makers, and reevaluation of objectives in response to changes. However, most systems experienced significant shortfalls in performance.

In a related activity, the Institute completed a detailed study in two Malaysian irrigation systems to assess the extent to which their performance was directly affected by the design of physical infrastructure. The study is one of a series initiated by the World Bank; its objective is to collate comparable data for systems around the world and draw conclusions concerning the impact of design and management interactions on performance.

In the Malaysian study, the downstream control technology incorporated in to one of the systems proved unsuccessful because of the failure

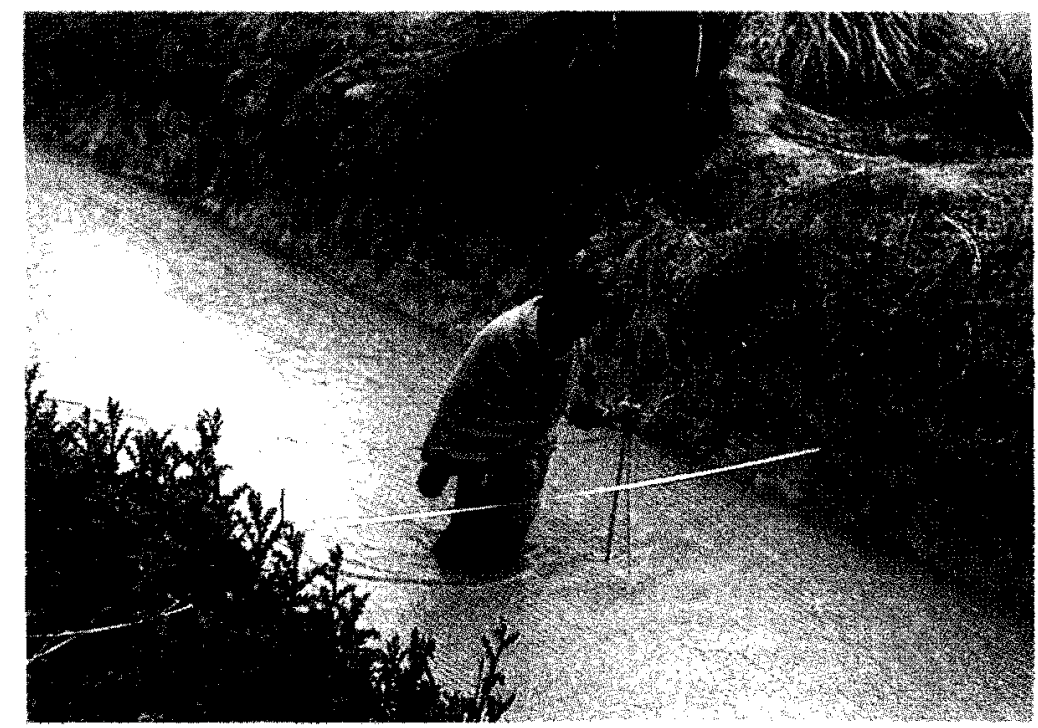

Canal flow measurements provide critical information on water distribution. 
of upstream pumps to deliver adequate water supply. Management responded by utilizing the downstream technology in an upstream control mode. In the second system studied, design had less to do with the performance than with management issues. Decreasing income from rice cultivation, compared with available off-farm employment, also contributed significantly to lower the anticipated performance.

\section{SImalating Canal Operations}

Few irrigation systems operate as originally envisioned by designers the larger and the more complex the system, more often than not, the greater is the diversion between its expected and real behavior. Rather than design failure, this simply reflects how hard it is to predict how a multitude of variables - weed growth, rainfall and, in manually operating systems, human behavior and response time - interact once the sluice gates of a reservoir are opened for the first time, and each time thereafter.

It is for this reason that scientists from IIMI and the French-based Centre National du Machinisme Agricole, du Génie Rural, des Eaux et des Forêts (CEMAGREF) began in 1987 to look for a way managers could experiment with and simulate the operation of a real life system. The Irrigation Department of Sri Lanka has been, from the inception of the project, an enthusiastic and critical collaborator.

The result: a mathematical flow simulation model of the 32-km long Kirindi Oya Right Bank Main Canal in southern Sri Lanka. The system was intended to irrigate about 5,000 hectares (ha), utilizing 33 distributary and field canals; in practice, the system has been able to deliver water to 3,650 ha. In the first phase, completed in 1990 , scientists working with the system's managers developed the simulation model software, calibrated the model to field conditions, and

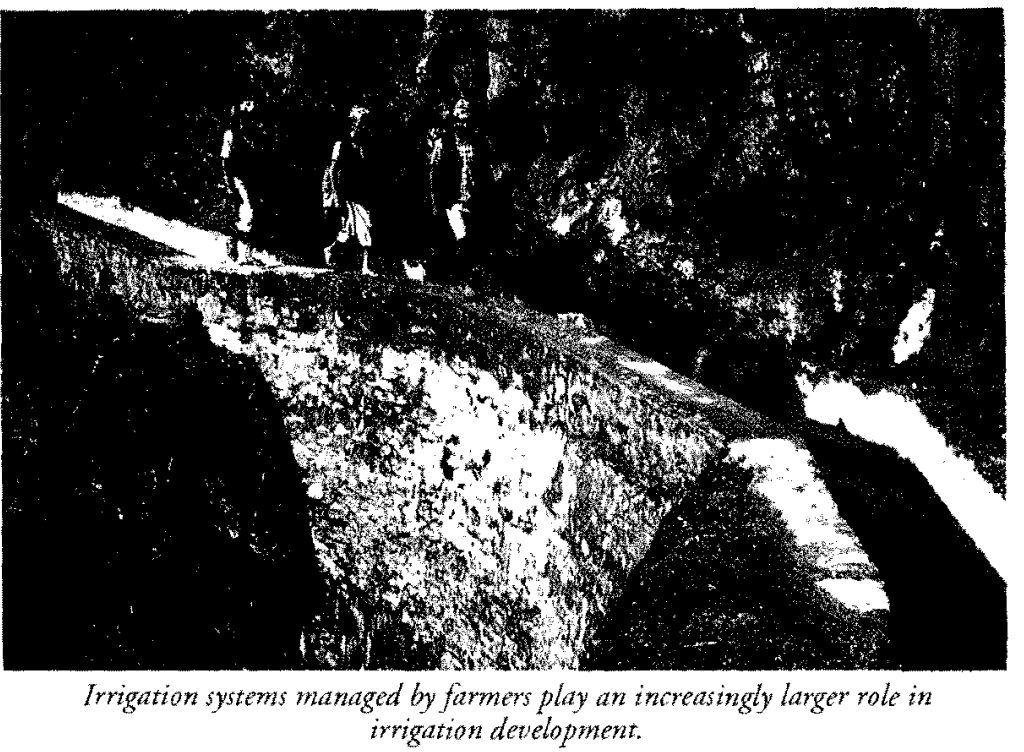

produced a set of operating manuals. The model is designed to run on a $\mathrm{PC}$ computer.

In 1991, scientists and irrigation staff began the second phase of the project - to field-test and evaluate the simulation model as a practical operational tool. This meant determining such factors as the amount and quality of information needed to run tests of a given scenario - say, rainfall in one part of the system - changes in attitude and additional training required of field staff, and organizational implications required for the model's implementation. The end result, expected in 1993, will be a decision-making support tool for the managers of manually operated canals.

\section{Farmer-Managed Irrigation Systems and Sapport Services}

Some of the world's oldest irrigation systems are those built and operated by farmers themselves. In some countries, like Nepal, they constiture more than half of the total irrigated area. These systems, referred to as Farmer-Managed Irrigation Systems (FMIS), range from small hill systems less than 100 ha, to large river diversion systems covering thousands of hectares, and can be found from Indonesia to Nigeria to Argentina. The arrangements for operating, maintaining and 
sharing the benefits of FMIS can be sophisticated and cost-efficient. However, only recently have governments begun to recognize the potential of farmer-managed irrigation for alleviating poverty and contributing to a nation's food supply, with relatively little assistance.

To help achieve this potential, in 1987, the Institute initiated a global research network on FMIS. The response has been impressive. In 1991, the network linked 1,300 irrigation professionals in 76 countries on six continents. The network, through its Advisory Committee, organizes workshops and study tours and promotes information exchange and the sharing of research results among participants through a network newsletter.

In March 1991, the network Advisory Committee, whose membership rotates among participants, held its fifth meeting in Manila, the Philippines, to review its achievements. Members identified several generic innovations produced by participants and outlined ways for their dissemination and application. In November, the network expanded its growing links with professionals of Latin America at its third international workshop in Mendoza, Argentina. The workshop, titled, Performance Measurement in Farmer-Managed Irrigation Systems, brought together 95 scientists from 25 countries.

In a related effort, IIMI and the German Foundation for International Development sponsored a workshop for mid-career professionals in Chiang Mai, Thailand in September and October. The three-part workshop exposed 24 irrigation practitioners to FMIS management concepts, reviewed the extent of FMIS in participants' home countries, and introduced strategies for assistance to FMIS.

At the heart of the network is IIMI's own research on FMIS. In 1991, the Institute completed the first phase of a three-year project to help government agencies and nongovernment institutions in Pakistan, Bhutan and Thailand develop appropriate strategies to assist the farmer- managed sector. The research also aims to develop assessment methods to enable managers and planners to reach informed decisions about options of intervention.

In Pakistan, Institute scientists documented the physical components and institutional features of three indigenous irrigation systems in Chitral District, North-West Frontier Province. In Thailand, scientists completed research on the People's Irrigation Project. Its unique feature is a "Mobile Campaign Unit," a multidisciplinary team of Thailand's Royal Irrigation Department and Forestry and Extension departments. In Bhutan, IIMI assisted local researchers in documenting organization and management practices of small-scale FMIS. Final results were presented at a national workshop in August, which was followed by the presentation of recommendations to the government.

At the same time, the Institute commissioned IIMI's former Head of the Nepal Country Program, to write three books based on 15 years of experience with FMIS. One book will document the author's research on FMIS in Nepal. Two other books examine locally managed irrigation systems and the design of irrigation structures in mountainous environments worldwide.

\section{Prlvatization and Tarnover}

Privatization of government industries, agencies and landholdings and the turnover of their management have swept across the developing countries. Irrigation Departments are no exception. Squeezed by rising costs and funding cutbacks, irrigation agencies have begun to reevaluate their roles and the potential role of nongovernment groups and water users.

In some cases, privatization has led to the transfer of ownership of assets or services - the provision of pumps, agricultural inputs - to private groups. In other cases, agencies have retained state ownership, but have sought to increase the role of users in operating and maintaining sections of large irrigation systems, or, 
where possible, entire systems. In both cases, changes can include decentralization of agencies, organization realignment, new financing arrangements and integrative arrangements for interagency planning and administration.

In the late 80 s, the Institute studied and facilitated management turnover in Indonesia and Sri Lanka. Today, similar efforts are being assessed in five of the ten countries where IIMI is directly working. study of management turnover from the US Bureau of Reclamation to local irrigation districts for the 550,000-acre Columbia Basin Project in Washington State, USA. The project attracted scientists' interest due to the success and scale of transfer, the length of time since it was completed (1969) and the availability of extensive data. Scientists studied the conditions leading to turnover, the turnover process and irrigation performance before and after.

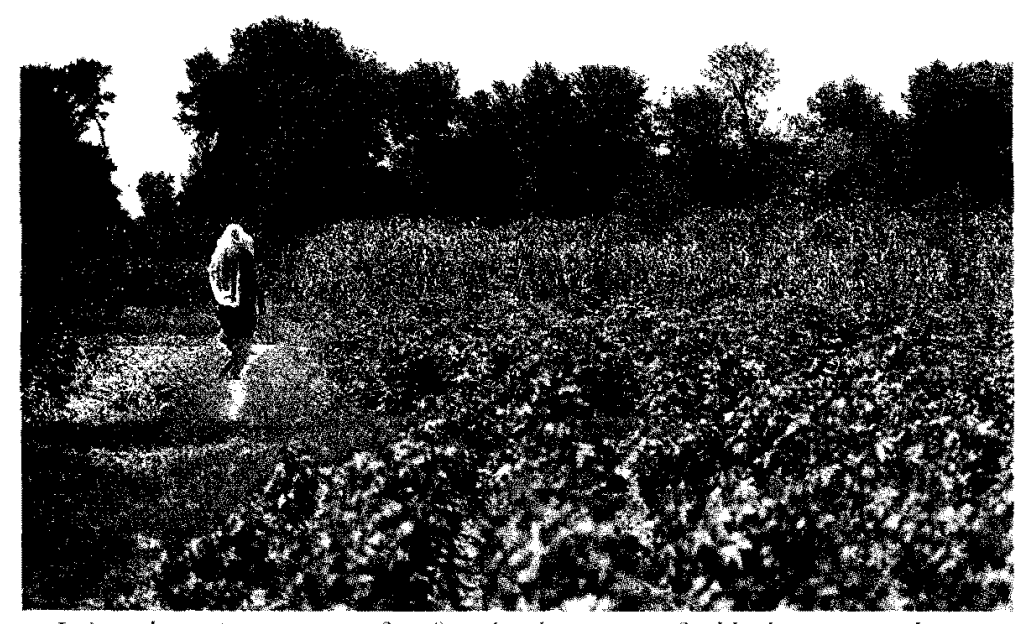

Irrigated nonrice crops are often fount to be more profitable than imigated rice.
Also in 1991, the Institute collaborated with a Sri Lankan research firm to assess the early stages of a national program to turnover management for distributary canals of large government schemes to local farmers' groups. Initial findings suggest rapid improvements in performance where farmers' organizations have readily accepted the responsibility for management.

\section{Crop Diversification Network}

One of the most dramatic developments affecting farmers in the past decade has been the fall in rice prices. As a result, farmers in developing countries, have had to
In 1991, the Institute initiated a thematic program to turn these research results into generic lessons for widespread dissemination. An IIMI scientist with experience in several countries, initiated the discussion with a paper entitled, "The Turnover and Self-Management of Irrigation Institutions in Developing Countries." The report describes irrigation privatization and management turnovers in Asia, Africa, and Latin America and provides a conceptual framework for identifying alternatives and working hypotheses about conditions shaping management transfer and its results.

In collaboration with the International Food Policy Research Institute and the Washington State University, the Institute completed a case become more competitive and versatile in the crops they choose to grow each year. In Asia, the most successful have been those farmers who grew nonrice crops in irrigated areas with well-drained soils during the dry season. Similar success has been shown on higher or porous lands in irrigated areas during the wet season. Irrigation agencies have been quick to respond to the changing needs. But it is not easy. Nonrice crops - onion, garlic, or mung bean, for example - have much more specific water needs, both in amounts and timing, than rice.

Between 1985 and 1990 , a large portion of IIMI's research in Asia - Sri Lanka, the Philippines, Indonesia and later Bangladesh was dedicated to identifying the constraints, 
potentials and solutions to growing nonrice crops in irrigation systems designed, constructed, and operated solely for rice production.

This work has been continued through the "Irrigation Management for Crop Diversification in Rice-Based Systems Network." The idea, first vetted at a regional workshop at the Institute's Sri Lankan headquarters in 1986, became a reality with the inauguration of the Network in late 1988. Today, it links researchers, irrigation and agricultural officials and policymakers from Bangladesh, India, Indonesia, Nepal, Malaysia, the Philippines, Thailand, Sri Lanka and Vietnam.

In September 1991, the Network held its second Annual Review and Coordination Workshop in Yogyakarta, Indonesia, co-organized by the Directorate General of Water Resources Development, the Gadjah Mada University and the Provincial Irrigation Service of Yogyakarta. Participants - senior officials from the nine countries, IIMI's Director General and four IIMI staff - reviewed national experience in promoting crop diversification. The proceedings are expected to be published in mid-1992.

The workshop was accompanied by the second issue of the Network newsletter. The newsletter is used as a forum for members to exchange experiences, ideas, news of emerging publications, results of other workshops and short abstracts of research reports. The Network also formed five national committees in the Philippines, Nepal, Bangladesh, Sri Lanka and Thailand, to oversee activities in those countries; similar committees in the remaining three countries are expected.

In a related effort, IIMI's field research with collaborating organizations in Bangladesh neared completion in 1991. This is part of a three-country collaborative project with the International Rice Research Institute; components in the Philippines and Indonesia were completed in 1990 . The results in Bangladesh were presented at two national workshops in that country.

\section{Health}

Most irrigation systems are created for a primary public health objective - to improve human nutrition. Their success in attaining this objective may sometimes be reduced by negative impacts on health. These are of two main types. Diseases borne by water-related vectors, especially mosquitoes and snails, may increase because the irrigated environment may support much greater populations of these vectors. Secondly, water provided for irrigation is often used for many other purposes such as drinking, cooking and washing. Gastroenteric and other diseases may be easily transmitted among people through these uses.

In 1988, the Institute joined hands with the UN-sponsored Panel of Experts on Environmental Management for Vector Control (PEEM), as part of the Panel's eleven collaborating centers. IIMI's formal designation in this role was accomplished in 1991. At the same time, the Panel broadened its own scope to incorporate water-related diseases other than vector-borne ones.

In August, the Institute and PEEM commissioned two internationally recognized scientists to visit Sri Lanka, Nepal and Pakistan and report back with recommendations as to how the Institute might address the relationship between irrigation and public health.

Beginning in 1992, IIMI will undertake research on these and other environmental issues under a new thematic program focusing on the environment.

\section{Women and Irrigation}

In the past decade, there has been a vast expansion of knowledge about the roles women fulfill in developing countries in farm production, commerce and other economic spheres. However, the contributions of women to irrigated agriculture and water management have been largely neglected as a research area. 


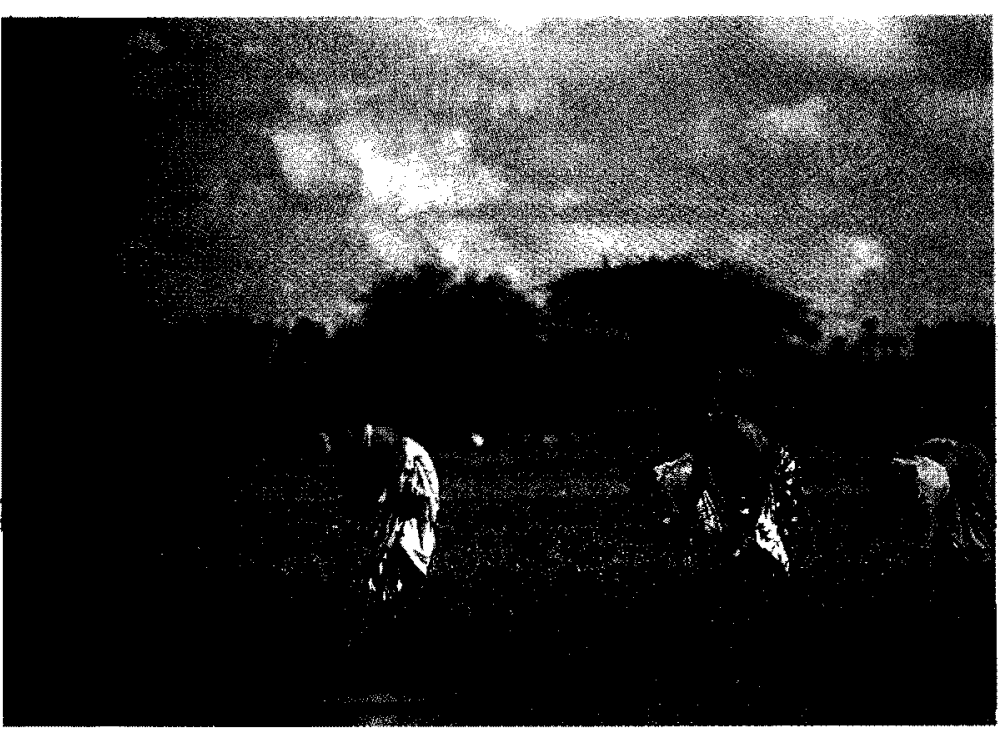

Future IIMI research will increasingly address gender issues.

In 1991, the Institute undertook to include gender issues in future research. As a first step,
IIMI commissioned a consultant to propose the future direction of the Institute's research on issues related to irrigation and gender.

An important task will be to find areas of congruence between the interests of women and those of irrigation managers and policymakers. For example, in areas where groundwater development has been undertaken, notably in India and Bangladesh, there is growing interest in women's roles as investors, pump irrigation managers and water users in home gardens. In Bangladesh, some nongovernmental groups are already training women in managing irrigation pumps.

\section{Country Programs}

IIMI's collaborative field research and action research at country level are conducted through specific projects in active collaboration with national agencies. This research is normally conducted in countries where IIMI has sustained resident programs. These country programs are designed to contribute to IIMI's overall research and research-related objectives and to the growth of national efforts in irrigation management research and development. In addition, they are implemented so as to maintain effective and productive relationships with national organizations concerned with the management of irrigated agriculture.

Four regions have been identified in IIMI's strategy as appropriate and distinctive units in which it will operate. They are South and
Southeast Asia, West Asia and Northeast Africa, Northwest and West Africa and Latin America and the Caribbean.

IIMI's early focal area was South and Southeast Asia, because of the importance of irrigation to its agriculture sector. In the late 1980s, IIMI's program spread to include countries in West Asia and Northeast Africa where agricultural production is almost wholly dependent on irrigation. The Institute has also expanded its research activities in Northwest and West Africa where irrigation is a feature of increasing significance to agricultural development. IIMI is currently taking steps to initiate programs in Latin America where there is a growing need to improve irrigation performance to increase food production. 
The year 1991 saw considerable growth and achievement in IIMI's country programs. More importantly, the impact of the work programs implemented over several years was felt at the national level in several countries where IIMI has been operating. The programs expanded particularly in the West Africa Region where new activities designed to have a regional impact have been initiated. Several new projects have also been launched in Asia. Negotiations are currently

\section{South and Southeast Asia}

This region is characterized by predominantly rice-growing irrigation systems. Climates generally display at least one season of generous rain which supports large areas of rain-fed as well as irrigated nonrice crops. Although nonirrigated production is strong, dependence on irrigation for a staple food crop is significant due to very high population densities. But in recent years, the zone underway for commencing new programs in Bangladesh, the Philippines, Morocco and Mali.

In several countries IIMI is operating in, the activities are getting diversified and have consequently assumed a programmatic nature. The phenomenon of national agencies and other groups coming to IIMI for assistance has been evident in practically all country operations, but principally in Sri Lanka, Nepal, the Philippines, Sudan and West Africa. has achieved notable success in increasing its rice production faster than its population growth, which has presented some new management issues such as marketing and diversification away from rice. The major countries of the zone are Bangladesh, Myanmar, India, Indonesia, Cambodia, Laos, Malaysia, Nepal, Sri Lanka, Thailand, the Philippines and Vietnam.

\section{SRI LANKA}

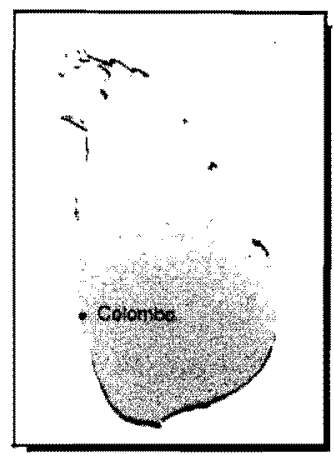

Sri Lanka, the home of IIMI's headquarters, has been experimenting for several decades with new ways to encourage people's participation in rural development. More recently, government and nongovernment institutions have implemented a number of pilot activities for enhancing farmers' participation in irrigation management. In the last decade, the government actively encouraged these efforts and began incorporating their lessons into its policies. In 1988, the government formally adopted a "participatory management policy" for irrigation system management, which sought to devolve authority and responsibility for system management to farmers' organizations, with support from state agencies.

Since its founding in 1984, the Institute has worked closely with the government in implementing these and other initiatives through a combination of policy research and analysis and field studies. Research topics have ranged from irrigation management for diversified crops to the rehabilitation of ancient irrigation tanks to 


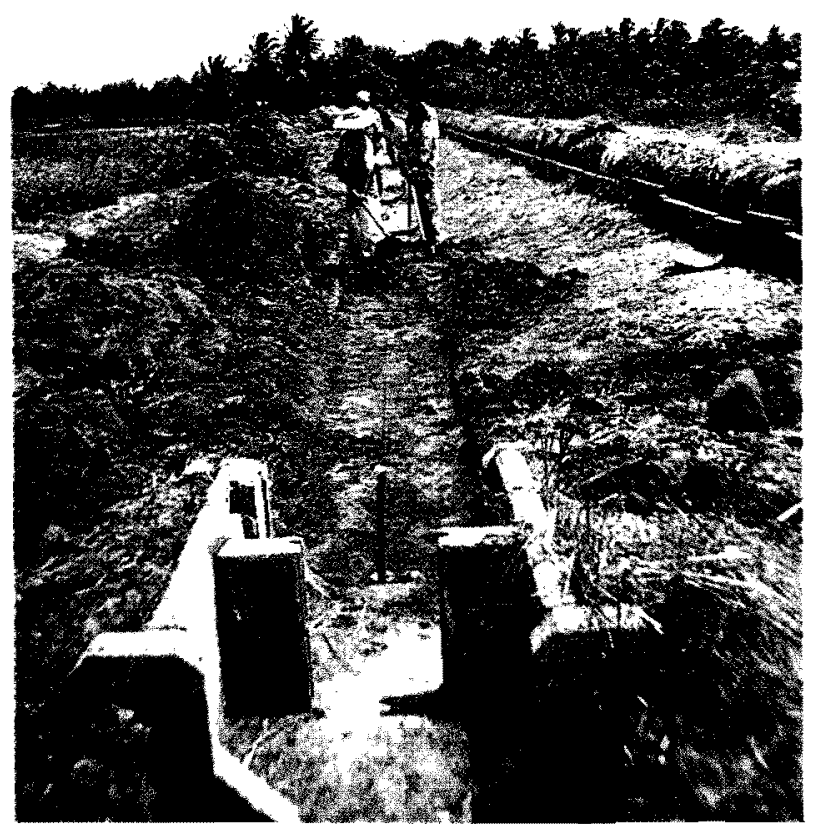

In Sri Lanka, the Institute has carried out research on rehabilitation and modernization of irrigation systems.
IMPSA is being implemented by a Secretariat of Sri Lankan professionals, and is guided by a high-level Irrigation Management Policy Advisory Committee (IMPAC). The Institute provides office and technical support services to the Secretariat, while Secretariat members, consultants and Institute staff prepare draft working papers in consultation with panels of experts; for each paper, the Secretariat organizes a series of consultative workshops with a spectrum of people ranging from farmers to irrigation managers. From there, the papers are further refined by IMPAC, who after reaching a consensus, forwards recommendations to the government for formal induction into policy.

Six policy papers, which Institute staff helped draft, were completed and approved by IMPAC in 1991. These set out a broad vision of the future of irrigated agriculture and provided: 1) specific guidelines for developing system-level selfmanagement and joint-management systems based on strong farmers' organizations; and 2) basic policies in regard to operation and maintenance, performance monitoring and financing. Other papers proposed specific and far-reaching changes in the mandate, staffing and organization of leading implementing agencies and provided an

modernizing large-scale irrigation systems. In carrying out these projects, a common thread has been a strong emphasis on using a participatory approach as a mechanism for ensuring relevance to the user and the country, thereby developing a commitment to the results.

One of the Institute's most visible activities during 1991 was its involvement in the Irrigation Management Policy Support Activity (IMPSA). Funded by the United States Agency for International Development (USAID), IMPSA uses a unique process for elaborating and refining the government's participatory management policy and for developing a wide consensus on the institutional reforms and strategies.

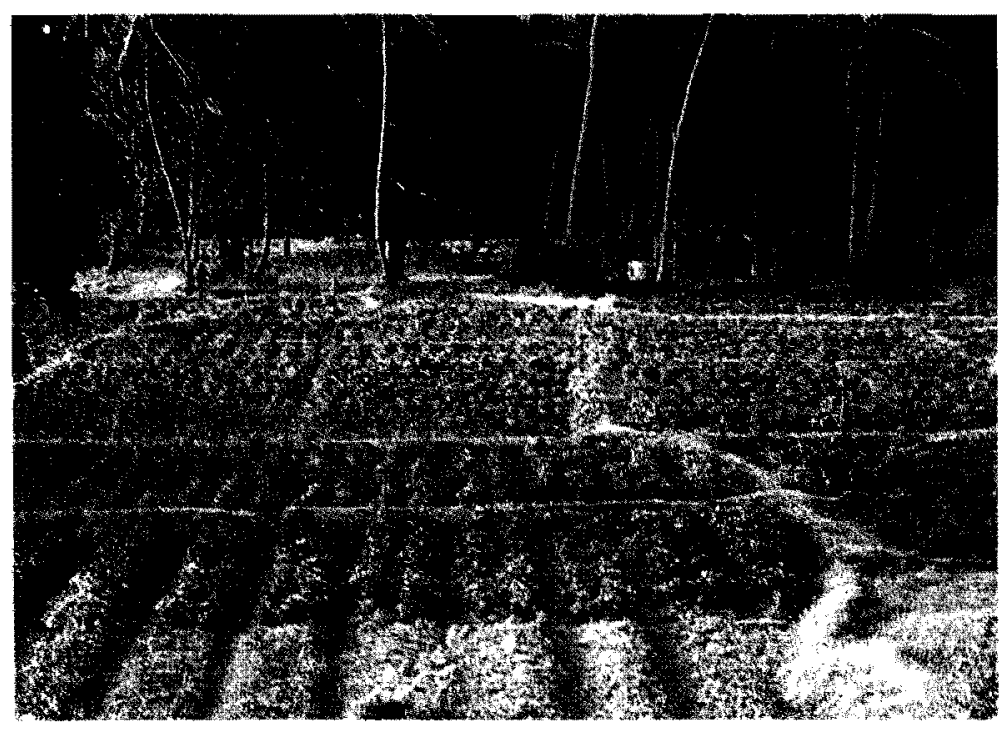

IIMI's program in Sri Lanka includes field research relevant to irrigation management for crop diversification. 
overview of a future water resources policy, the basis of a master planning activity scheduled to begin in 1992 .

In a related effort, IIMI sponsored a national workshop early in the year to review proposals for future investment strategies. Participants agreed that the concepts of operation and maintenance of existing irrigation systems, institutional strengthening, and research and development should take priority in the government's future investment strategy.

In field research, Institute staff began fieldtesting and implementing innovations which emerged from IIMI research in two large irrigation systems in southern Sri Lanka. The Institute is using this project to refine a methodology for using action research as a mechanism for organization strengthening and professional development. Called "Participatory Action Research" the methodology establishes a subcommittee consisting of project and field officers, Institute staff, and where appropriate, farmer representatives. The subcommittee plans and implements the activity, collects, and analyzes and evaluates the data.

Also during 1991, staff continued to oversee several research projects carried out by national institutions as part of USAID's Irrigation Systems Management Project. An important aspect of the
Project is to evaluate alternative strategies for rehabilitating irrigation schemes in a cost-effective manner. In one study on the profitability of agriculture in four large schemes in the eastern Polonnaruwa District, researchers found rice yields had stagnated; but wide variations in yields suggested room for improvement. The study indicated that returns from rehabilitating the schemes may not match the costs.

In another study, researchers evaluated the process of turning over management responsibilities of six distributary canals to farmers' groups of irrigation systems in Polonnaruwa District. Results showed a wide variation in the management success of farmers' organizations; the best organization improved subsystem performance and diversified into other incomegenerating activities. But farmers need additional training in financial management skills and more support from field staff.

Also during the year, staff completed a number of activities related to farmer-managed irrigation systems. Two reports presented authors' evaluations of different strategies for government intervention in small-scale irrigation schemes. A third report compared the sustainability of two small systems previously rehabilitated, one by the government and the other by a nongovernment organization.

\section{The Philippines}

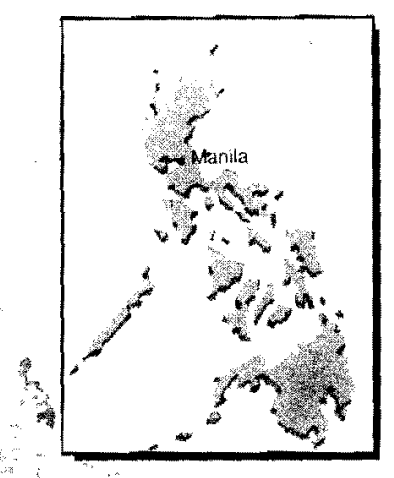

In the past three decades, the Philippines has consistently searched for new ways to improve irrigation management. The National Irrigation Administration (NIA) pioneered the movement in developing countries toward farmer participation in irrigation.

The Philippines was among the first to respond to the fall in commodity prices by searching for new irrigated crops to grow. And, 


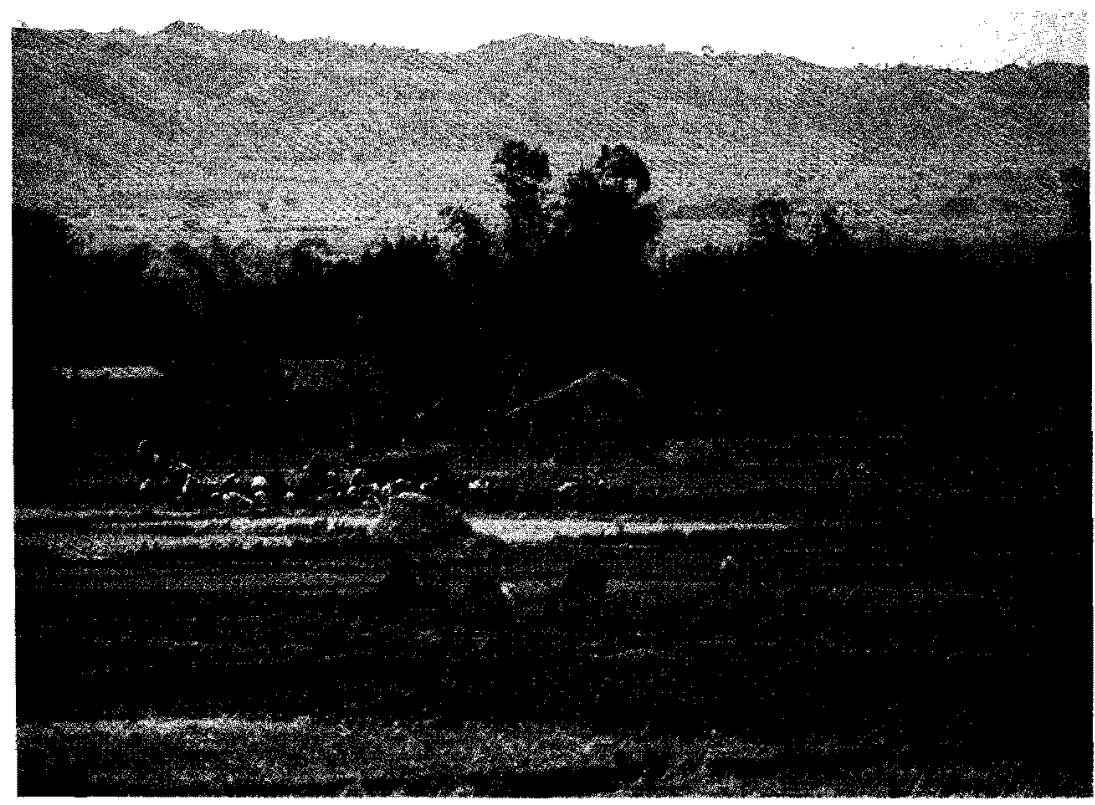

In the past three decades, the Philippines bas consistently searched for new ways to improve irrigation wanagement.

performance. The focus is on two types of irrigation systems:

National Irrigation Systems which are owned and constructed by the government but jointly managed by NIA and Irrigators' Associations through differing contractual agreements; and Communal Irrigation Systems, which are owned and managed solely by farmers with assistance from NIA.

In 1991, IIMI in collaboration with nine regional universities, and NIA regional offices, completed 14 research

long before the word "privatization" became fashionable, the National Irrigation

Administration (NIA) was again among the first to act: NIA began financing its operating budget entirely from its own revenues as early as 1982 .

Three years later, IIMI established its first field office in the Philippines. It has worked closely with NLA, regional universities and farmers" organizations ever since to strengthen the national research capacity, document innovations and disseminate the results to other countries where similar moves are underway.

In 1991, Institute scientists in the Philippines completed the first phase in the research component of the Accelerated Agricultural Production Program. Financed by USAID, the Program's research objective is to identify, develop, field-test and evaluate innovations to strengthen the capacity of Irrigators' Associations, farmers' organizations and NIA to improve irrigation projects. Final reports examined the performance of systems managed by Irrigators' Associations, reviewed the strengths and weaknesses of interaction between the associations and NIA, evaluated the interaction between design and management of Communal Irrigation Systems and considered the effectiveness of NIA's Farmers Irrigator's Organization Program. In addition to the results, the program led to lasting ties between NIA and the nation's regional network of universities.

Based on the findings of these projects, IIMI, NIA and the universities went on to conduct a one-year pilot test of proposed interventions in four more projects. The results of these and other projects were reported in final drafts of four major research publications, 14 project reports, three country reports, and seven research papers prepared for workshops and seminars outside the country. In addition, Institute scientists provided technical inputs into three Irrigation Training Manuals completed by NIA. 


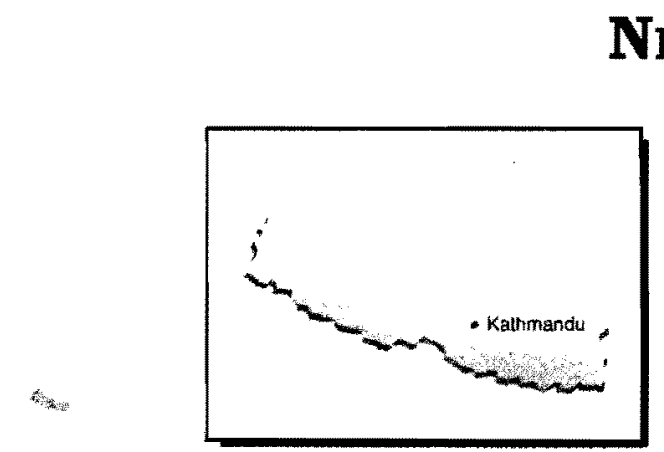

Even before democracy swept into Nepal last year, the country's irrigation agencies had seen the wisdom of increasing the participation of people in government - in this case, farmers. In 1989 and 1990 , the Irrigation Master Plan gave new emphasis to participatory and joint management and system turnover as the linchpins in the government's program to make farmers partners in development. Farmers already manage more than 60 percent of Nepal's irrigated area.

IIMI has carried out five years of collaborative research in Nepal on these issues. Among the innovations that have emerged in that time are a cost-effective reconnaissance procedure for ranking farmer-managed systems in terms of need; a rapid appraisal procedure to rank the necessary assistance in terms of impact; the use of farmers from wellmanaged systems to train farmers from lessefficient systems (i.e., peer training); and the use of farmers as consultants in designing system improvements. Institute scientists are now adapting these and other innovations for use by the Department of Irrigation in its new program.

For example, in 1991, IIMI in collaboration with the District Irrigation Office in Kapilavastu used peer training to prepare farmers for participating in the management of the Banganga Irrigation System, a large, formerly government- operated scheme. Once formed into an organization, farmers: i) cleaned about $30 \mathrm{~km}$ of canals and field channels; and ii) formulated rules and regulations for regular maintenance by the organized water user groups. Activities are also underway to organize farmers along the entire system. Moreover, Institute staff found that an active and dedicated government manager was critical to the task of organizing farmers.

Also in 1991, the Institute completed a study to document and evaluate a program of the Agricultural Development Bank of Nepal to assist the small-scale irrigation sector. The Bank provides irrigation packages that include irrigation technology and financial, technical and organizational hardware to farmer groups. Scientists found that the packages are cost-effective in increasing production and that the internal rate of return was substantially greater than the Bank's assumed costs of funds.

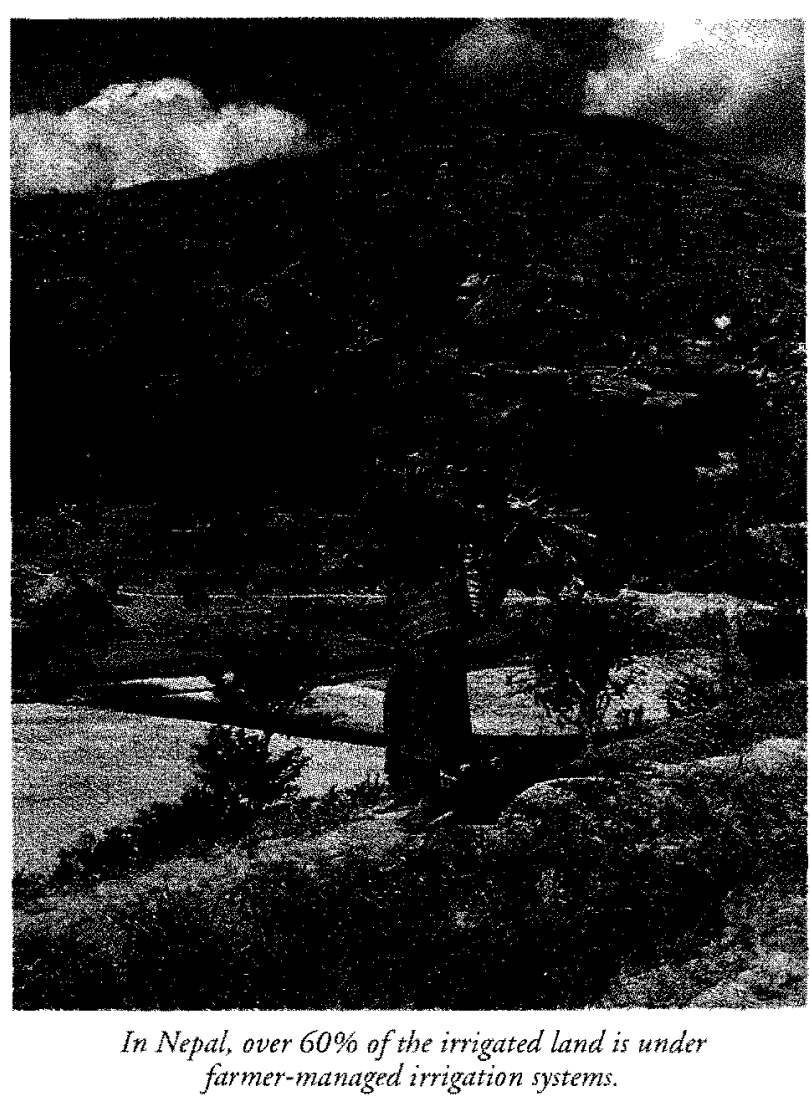




\section{INDIA}

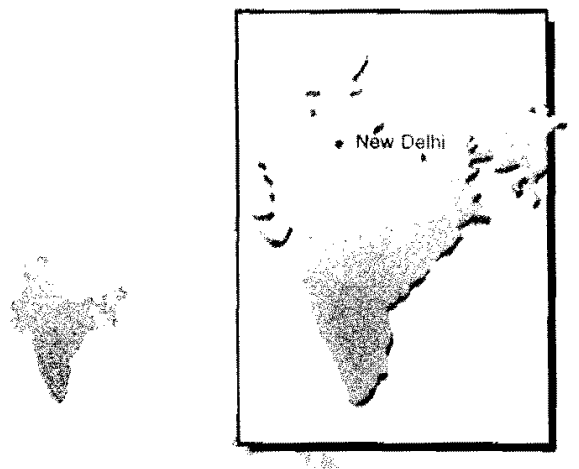

Few countries in the world have expended more effort with more success than India has done in developing its water resources. Irrigation has essentially eradicated the threat of famine in the subcontinent and in many states it has created the excess capital necessary to expand industry.

However, much of the gains has come in sheer expansion rather than in improved management. And as India begins to liberalize its economy, as happened last year, improving the performance of irrigation to create farm income in rural areas becomes critical to sustaining the success of the new policy. Agriculture remains the engine of growth, and the majority of India's estimated 500 million people continue to toil in rural areas.

Given India's size and diversity and the number of qualified irrigation engineers and researchers, the Institute has pursued a non resident collaborative approach to its work on the subcontinent. The program, begun in 1989, is aimed at strengthening the capacity of selected Indian institutions to carry out interdisciplinary management research and demonstrate the capability of improving irrigation performance through field research. It involves some 40 researchers, including visiting Institute staff from Colombo, who are carrying out projects in four states - Tamil Nadu, Gujarat, Uttar Pradesh and Bihar - chosen to reflect a range of conditions. Implementation of the projects began in earnest in 1991.
In Tamil Nadu, staff from Madras-based Anna University, Trichy-based Irrigation Management and Training Institute and the Irrigation Wing of the Public Works Department, began researching the performance and main system management of the Tamiravaruni Irrigation Scheme. Social scientists are evaluating existing farmers' organizations and their interaction with main system management. Engineers have installed flow measuring equipment, calibrated the structures and have begun collecting flow data. Other team members will be documenting the decision-making process and studying the interaction between different governmental agencies involved with the project.

In Gujarat, staff of the Water and Land Management Institute, the Institute for Rural

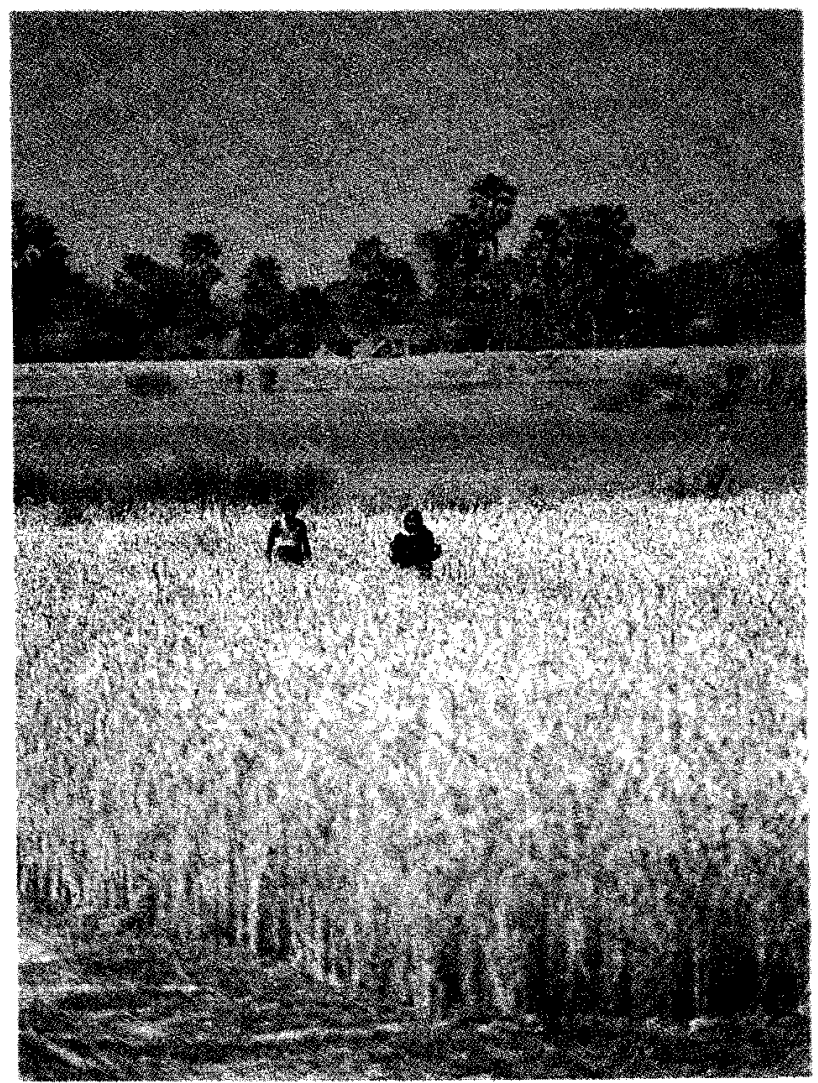

Improved irrigation management is a feature of increasing significance to agricultural development in Bibar. 
Management, Anand and Gujarat's Water Resources Department are carrying out similar studies on the Mahi-Kadana Project. In addition, special emphasis will be given to developing an interactive methodology of water delivery schedules on minor canals and the formation of farmers' groups.

In Uttar Pradesh (UP), the University of Roorkee, UP Water and Land Management Institute and the Irrigation Department are working in three pilot areas on the conjunctive use and management of groundwater for irrigation in the as-yet-unfinished

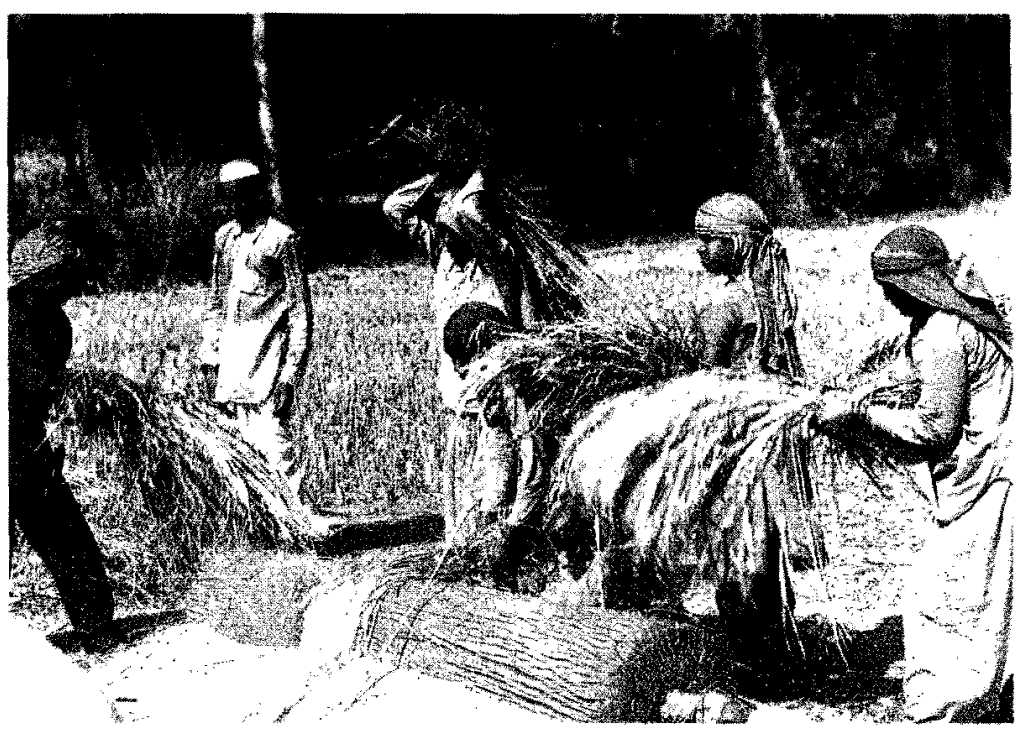

Agriculture remains the most vital component of development in India. Madhya Ganga Project. Studies are underway to assess groundwater behavior and the extent of groundwater resources. A systematic soil survey study is also being conducted to identify diversified land uses and associated management practices. Socioeconomic studies are also underway.

Last, in Bihar, the Patna-based Bihar College of Engineering, the Bihar Water and Land

Management Institute and the Irrigation Deparment are analyzing issues related to conjunctive use of surface water and groundwater resources in the Eastern Gandak Project. The surface irrigation infrastructure has not yet been completed due to severe waterlogging, a major obstacle to agricultural production throughout India's poorest state.

\section{Bangladesh}

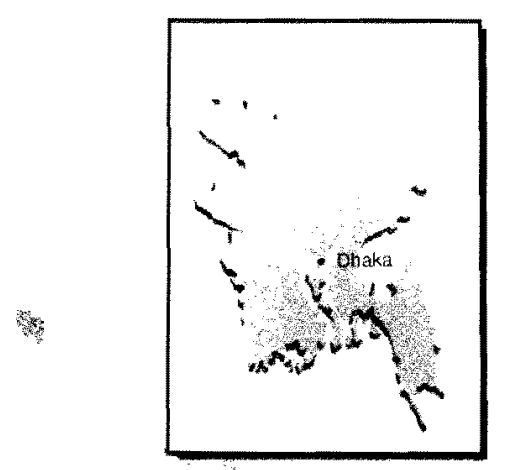

Last April, a massive cyclone sent a six-meter wall of water over the coast of Bangladesh killing more than 100,000 people and destroying millions of dollars of crops. Almost by itself, the cyclone cut the 5.8 percent GNP growth rate of 1990 almost by half in 1991 . It also led to another round of emergency food imports.

Despite being prone to such narural disasters, however, Bangladesh continues to have the potential for substantial agricultural growth. Although virtually all of the country's nine million hectares of cultivable land are already under use, Bangladesh's vast irrigation potential, unlike its Asian neighbors, has barely been tapped. Independent estimates suggest that there is enough water to triple the current area under irrigation. The application of controlled water supplies to the fertile soils of the floodplains of the Ganges, Brahmaputra and Meghna rivers could lead to a substantial increase in agricultural production and 
rural incomes. The combination could provide the necessary margin of safety against future disasters and turn the tide against poverty.

Two key factors set Bangladesh apart from other countries where the Institute is currently working. First is the predominance of lift irrigation - tubewells as well as motorized pumps drawing from surface supplies - versus canals. Second is the need to increase rice yields to a scale comparable with other developing Asian countries. The national program of irrigation development is responding to both these needs by trying to rapidly expand the irrigated area and to better utilize existing resources. In particular, the government has placed heavy emphasis on privatizing the installation of pumps and the management of the pump irrigation sector.

To assist in this process IIMI, the International Rice Research Institute and several national cooperating institutions initiated research in 1988 as part of a three-country project entitled "Irrigation Management Options for Rice-Based Farming Systems."

In 1991, as part of this effort, researchers continued and expanded field tests of an innovative water delivery plan in the GangesKobadak Irrigation System, a large lift canal scheme operated by the Bangladesh Water Development Board. In earlier phases of this study, researchers and irrigation staff had implemented a ten-day rotation (five days on, five days off) of water delivery to farmers in one secondary canal and its system of tertiary canals.

The project staff's commitment to ensure water delivery and the involvement of farmers in carrying out the new schedule resulted in a substantially larger irrigated area compared to previous dry seasons. Last year, the research team repeated and sustained the results along the canal studied in 1990 and also successfully expanded the program to three other secondary canals.
In the North Bangladesh Tubewell Project (NBTP), Institute staff evaluated the transfer of ownership of many of the project's deep tubewells to the Grameen Bank under the national privatization program. Grameen has gained world renown for the development of innovative ways to provide credit to the poor. Its expansion into tubewell management is a fairly recent initiative. Under its program, the Bank purchases a deep tubewell and contracts with farmers to exchange one quarter (or more, if inputs are provided) of their harvest for a share of water. A bank employee lives and works at the site and runs all aspects of the operation including water management.

The Bank, however, has had mixed results in implementing the program in the NBTP area. Farmers, who had grown used to paying minimal charges (if any) to the Water Development Board, resisted the idea of contracting and later paying the Bank's share of their harvests. Grameen also suffered losses due to low yields and high management costs.

In Rajshahi, researchers evaluated performance, fee collection and farmer participation in the management of three types of deep tubewells: private, rented and public. Among these, the privately managed wells appeared to irrigate larger areas with the same amount of water. All three, however, showed higher rates of farmer participation in management and costs than was evident in the Ganges Kobadak and NBTP study sites.

Results of research and recommendations for improving performance at all three sites were presented at an October workshop held at the Bangladesh Agricultural Research Council. Representatives of irrigation agencies, government ministries and research institutions participated in this workshop. 


\section{West Asia and Northeast Africa}

Major rivers originating in mountain systems fringing the zone carry plentiful silt and have laid down deep, level and fertile soil systems. The average annual rainfall is generally very low and many of the countries in the region depend almost totally on irrigation for food and fiber crops. Human populations crowd the irrigated areas because nonirrigated food production capacity is low. In many systems, virtually all surface water resources have been captured so that improved management to increase productivity per unit of water is the only way forward. The major irrigation countries of the zone are Pakistan, Iran, Iraq, Syria, Egypt and Sudan.

\section{Pakistan}

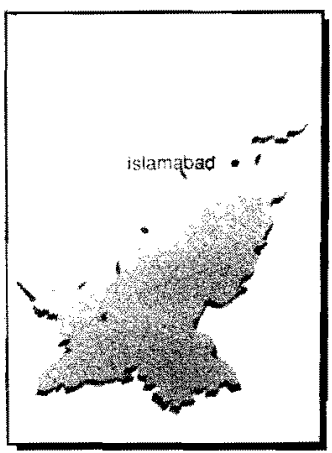

Placed end to end, Pakistan's major irrigation canals could stretch around the world more than four times. Add almost 300,000 tubewells and Pakistan ranks fifth in the world in gross irrigated area with 16 million hectares. At the same time, comprehensive studies have shown the Indus Basin to be one of the world's most favorable environments for intensive, highly productive irrigated agriculture. The International Food Policy Research Institute believes Pakistan and Thailand are the only two countries in Asia with the potential to export food on a sustainable basis in the 21 st century.

However, with all that in its favor, the government still predicts shortfalls in national food and fiber requirements to the tune of 10 percent by the year 2000 and of 25 percent in 2013. And, that assumes Pakistan can meet targets set by the national "Water Sector Investment Plan" of 1990. Not surprisingly, good quality surface water supplies are said to be the nation's scarcest, most valuable agricultural resource. With more than rwo-thirds of Pakistan's 110 million people engaged in agriculture, returns to investment in improved irrigation management strategies will yield tremendous social and economic benefits.

The Institute's program in Pakistan, begun in 1986, continues to develop and adopt management innovations consistent with the awareness shown by the country's policymakers of the need to improve irrigation management. Working closely with federal ministries of Water and Power, and Food and Agriculture, provincial irrigation staff and national research institutions, the Institute's staff have developed indices to monitor the equality of water delivery, developed assessment methods to target canal maintenance, and have shown the importance of the first irrigation of wheat, which frequently conflicts with the annual closure of canals.

In 1991, Institute staff continued research on waterlogging and salinity. Spreading salinity caused when salt moves upward through the soil with rising water tables, or when irrigation water is pumped from groundwater of doubtful quality 
rural incomes. The combination could provide the necessary margin of safety against future disasters and turn the tide against poverty.

Two key factors set Bangladesh apart from other countries where the Institute is currently working. First is the predominance of lift irrigation - tubewells as well as motorized pumps drawing from surface supplies - versus canals. Second is the need to increase rice yields to a scale comparable with other developing Asian countries. The national program of irrigation development is responding to both these needs by trying to rapidly expand the irrigated area and to better utilize existing resources. In particular, the government has placed heavy emphasis on privatizing the installation of pumps and the management of the pump irrigation sector.

To assist in this process IIMI, the International Rice Research Institute and several national cooperating institutions initiated research in 1988 as part of a three-country project entitled "Irrigation Management Options for Rice-Based Farming Systems."

In 1991, as part of this effort, researchers continued and expanded field tests of an innovative water delivery plan in the GangesKobadak Irrigation System, a large lift canal scheme operated by the Bangladesh Water Development Board. In earlier phases of this study, researchers and irrigation staff had implemented a ten-day rotation (five days on, five days off) of water delivery to farmers in one secondary canal and its system of tertiary canals.

The project staff's commitment to ensure water delivery and the involvement of farmers in carrying out the new schedule resulted in a substantially larger irrigated area compared to previous dry seasons. Last year, the research team repeated and sustained the results along the canal studied in 1990 and also successfully expanded the program to three other secondary canals.
In the North Bangladesh Tubewell Project (NBTP), Institute staff evaluated the transfer of ownership of many of the project's deep tubewells to the Grameen Bank under the national privatization program. Grameen has gained world renown for the development of innovative ways to provide credit to the poor. Its expansion into tubewell management is a fairly recent initiative. Under its program, the Bank purchases a deep tubewell and contracts with farmers to exchange one quarter (or more, if inputs are provided) of their harvest for a share of water. A bank employee lives and works at the site and runs all aspects of the operation induding water management.

The Bank, however, has had mixed results in implementing the program in the NBTP area. Farmers, who had grown used to paying minimal charges (if any) to the Water Development Board, resisted the idea of contracting and later paying the Bank's share of their harvests. Grameen also suffered losses due to low yields and high management costs.

In Rajshahi, researchers evaluated performance, fee collection and farmer participation in the management of three types of deep tubewells: private, rented and public. Among these, the privately managed wells appeared to irrigate larger areas with the same amount of water. All three, however, showed higher rates of farmer participation in management and costs than was evident in the Ganges Kobadak and NBTP study sites.

Results of research and recommendations for improving performance at all three sites were presented at an October workshop held at the Bangladesh Agricultural Research Council. Representatives of irrigation agencies, government ministries and research institutions participated in this workshop. 


\section{West Asia and Northeast Africa}

Major rivers originating in mountain systems fringing the zone carry plentiful silt and have laid down deep, level and fertile soil systems. The average annual rainfall is generally very low and many of the countries in the region depend almost totally on irrigation for food and fiber crops. Human populations crowd the irrigated areas because nonirrigated food production capacity is low. In many systems, virtually all surface water resources have been captured so that improved management to increase productivity per unit of water is the only way forward. The major irrigarion countries of the zone are Pakistan, Iran, Iraq, Syria, Egypt and Sudan.

\section{Pakistan}

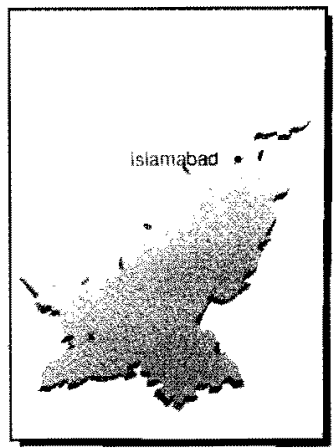

Placed end to end, Pakistan's major irrigation canals could stretch around the world more than four times. Add almost 300,000 tubewells and Pakistan ranks fifth in the world in gross irrigated area with 16 million hectares. At the same time, comprehensive studies have shown the Indus Basin to be one of the world's most favorable environments for intensive, highly productive irrigated agriculture. The International Food Policy Research Institute believes Pakistan and Thailand are the only two countries in Asia with the potential to export food on a sustainable basis in the 21 st century.

However, with all that in its favor, the government still predicts shortfalls in national food and fiber requirements to the tune of 10 percent by the year 2000 and of 25 percent in 2013. And, that assumes Pakistan can meet targets set by the national "Water Sector Investment Plan" of 1990. Not surprisingly, good quality surface water supplies are said to be the nation's scarcest, most valuable agricultural resource. With more than two-thirds of Pakistan's 110 million people engaged in agriculture, returns to investment in improved irrigation management strategies will yield tremendous social and economic benefits.

The Institute's program in Pakistan, begun in 1986, continues to develop and adopt management innovations consistent with the awareness shown by the country's policymakers of the need to improve irrigation management. Working closely with federal ministries of Water and Power, and Food and Agriculture, provincial irrigation staff and national research institutions, the Institute's staff have developed indices to monitor the equality of water delivery, developed assessment methods to target canal maintenance, and have shown the importance of the first irrigation of wheat, which frequently conflicts with the annual closure of canals.

In 1991, Institute staff continued research on waterlogging and salinity. Spreading salinity caused when salt moves upward through the soil with rising water tables, or when irrigation water is pumped from groundwater of doubrful quality 


\section{Annual Report 1991}

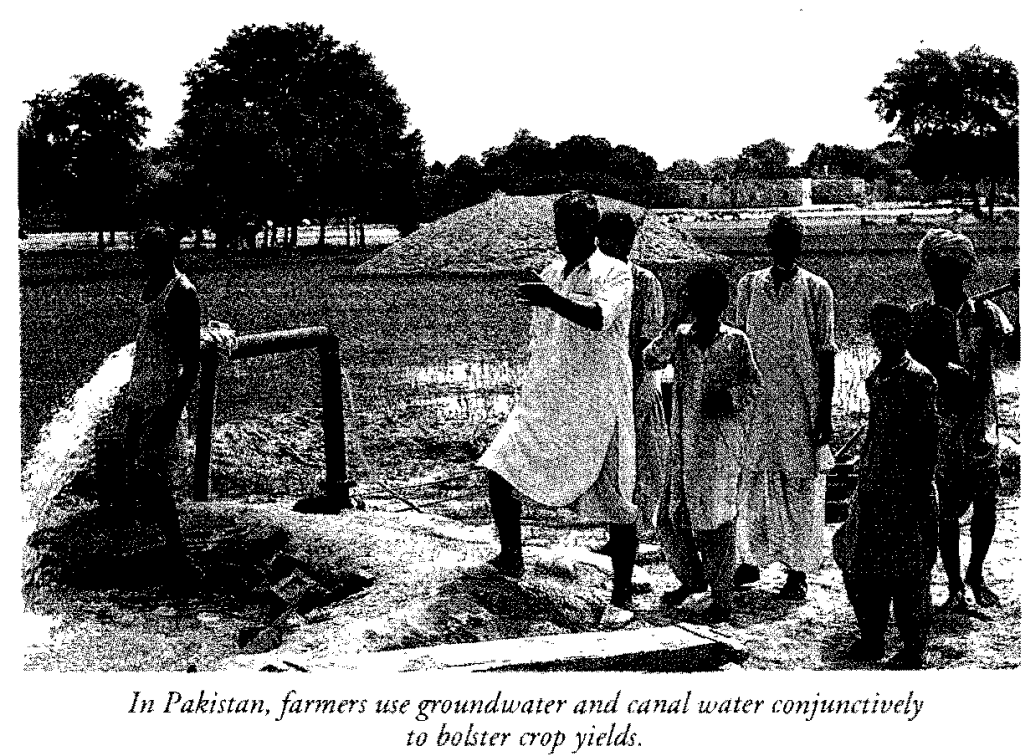

which takes an increasing importance - takes thousands of hectares of farm land out of production, with nearly irreversible consequences. Earlier studies on the topic, begun in 1988, found a link between inequitable water delivery to the head, middle and tail portions of canals and increased incidence of salt accumulation in the soils in water-deficit locations. Farmers who did not receive their scheduled water delivery made up the difference with tubewell supplies; but the same tubewell water was found to have high salt contents.

Last year, the Institute began testing ways to reverse the trend. Working on one canal with the Punjab Irrigation Department, IIMI demonstrated that, even with budgetary constraints, targeted maintenance can produce conditions that result in surface water deliveries much closer to the intended equity objective. Supplying increased amounts of better quality canal water to underserved areas, permits farmers to mix irrigation supplies, or to apply good quality and poor quality waters alternately. This improves the average quality of warer used, slows the rate of secondary salinization and reduces its impact on crop yields. In this regard, Institute staff began testing several components of a decision-support package to assist irrigation line officers in planning their annual canal maintenance.

At the request of federal and provincial authorities, IIMI scientists began work in 1991 in Pakistan's North-West Frontier Province. The Province has embarked upon two new projects; one is the remodeling of the physical infrastructure in the Lower Swat Canal; the second is the construction of the Chashma Right Bank Canal. IIMI has developed an applied research project to develop a crop-based operational strategy to improve productivity of water resources in the two systems.

Pakistan's irrigation system continues to operate according to design objectives of British engineers who originally planned it. Many structures are fixed - as opposed to movable irrigation gates - so the system can run with a minimum of management personnel. As a consequence, the system delivers water on a fixed rotation; there is little room to deliver varying

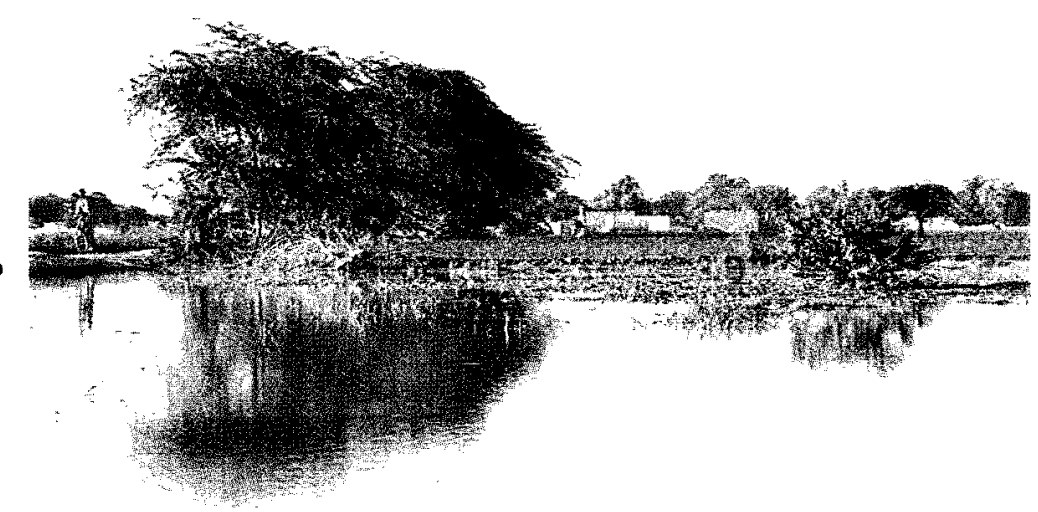

During 1991, researd on waterlogging and salinity continued in Pakistan. 
quantities of water to different crops in the same section of the system in accordance with the needs of the crops. So IIMI scientists, in this case, will be trying to determine the minimum amount of infrastructure and management changes necessary to adapt the systems to meet varying crop water requirements.

The Institute is also directly involved with a nationwide effort to upgrade large portions of
Pakistan's irrigation research network and to strengthen the research capacity of the institutions involved. IIMI's role is to provide technical assistance to participating national research institutions. In particular, the Institute is working closely with the International Waterlogging and Salinity Research Institute. The aim is to enhance the research management skills of the staff through "hands on" experience in planning, monitoring and evaluation of irrigation- and drainage-related research.

\section{Sudan}

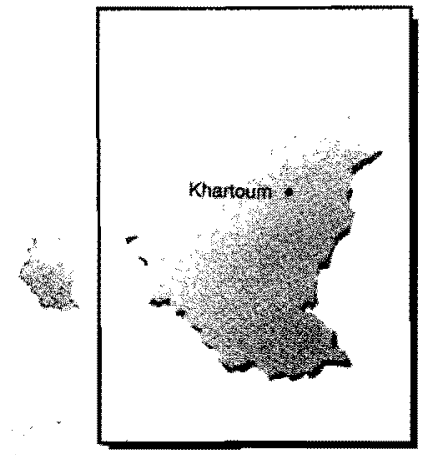

In a hot desert climate with errant rainfall like that of Sudan, and an impoverished population of 25 million people, the margin of error in irrigation performance is razor thin. A ten percent expansion of irrigated area or in the efficiency of delivery to existing areas can save the lives of thousands of people in a single year of drought.

But Sudan has more irrigation than any other country in the zone save Egypt - almost 1.9 million hectares. While this amounts to only a quarter of the country's total cultivated land, nearly half of Sudan's food is produced on it, including all of Sudan's wheat and 90 percent of its cotton. The most prominent systems are the 60-year-old Gezira System, which accounts for a third of the irrigated area, and the more recent New Halfa and Rahad schemes. However, small systems make a significant contribution to cultivation.
Having finalized a long-term work plan with the government in 1990 , the Institute began field research in Sudan last year. In 1991, staff began working with the Ministry of Irrigation and the Rahad Agricultural Corporation to improve the operation and maintenance of the Rahad Irrigation Scheme. The first step was to find out just how well the system was working. To do that staff began by installing gauges, data loggers and other measurement devices along a major secondary canal. Data collection continued through the second half of the year, and will be complemented by surveys of water users and managers in early 1992.

In the first half of the year, an IIMI staff member assigned to the Sudan Gezira Board worked with top management staff and collaborating researchers to identify major obstacles to performance of the Gezira Scheme. Once completed, field research began at the scheme's pilot farm, in October, to quantify water and agronomic parameters and their impact on wheat production. Yields proved uncertain, and in some cases crops were lost altogether; sixteen majo shortcomings were identified, ranging from the hardiness of recently introduced wheat to a lack of flow measuring devices. Appropriate management strategies will be tested in 1992. 


\section{Annual Report 1991}

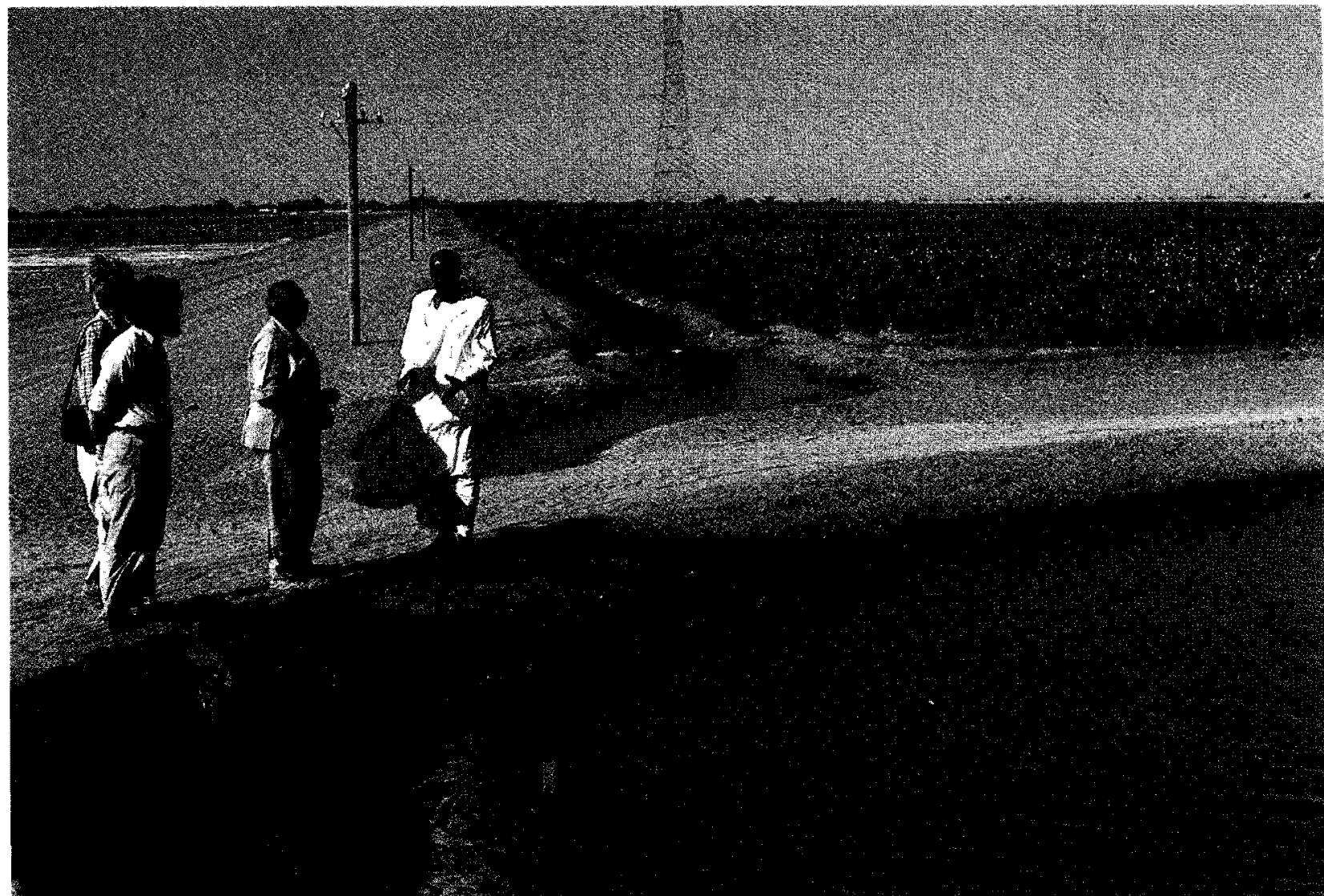

The 60-year old Gezira Scheme is about to undergo important changes in its agricultural and management systems.

In the area of training, staff organized two major workshops and conducted several short-term and long-term training courses. In May, staff collaborated with the Agricultural Ministry to sponsor a workshop on water charges. The participants reviewed present polices in regard to water charges, considered lessons from other countries, and identified a range of policy options for Sudan.

At the request of the ministers of Irrigation and Agriculture, the Institute assisted in organizing an October workshop on the subject of privatizing irrigation schemes. Lively discussions led to a series of far-reaching recommendations: these ranged from the establishment of water users' organizations to the turnover of various responsibilities for management of government systems to farmers. In Sudan, where farmers have heretofore had little say in management, or even about the crops they grow, this represented a revolution in thinking.

Also during the year, the Institute conducted a twelve-day training course on Rapid Rural Appraisal for nineteen participants from the Institute's collaborating government and nongovernment partners. Two IIMI staff from outside Sudan and the two resident IIMI staff joined a consultant in conducting the course. And throughout the year, staff conducted a series of short seminars on the Institute's experiences in other countries. And several senior officials from the Gezira Board were taken on a study tour of Bangladesh and Pakistan to see how officials in those country's deal with related problems. 


\section{Northwest and West Africa}

In this zone, reliance on irrigation has hitherto been quite low. Population densities are usually low and over great parts of the continent rain-fed production has sufficed to feed the population with irrigation concentrated on cash crops or export crops. A trend toward more irrigation for staple food production is now emerging as populations grow and pressure on food resources increases. However, unlike in other zones, irrigation traditions and infrastructure are lacking, so institutional formation is a management issue here. Nigeria, with the continent's highest population, is the most significant irrigator country in the zone.

\section{MOROCCO}

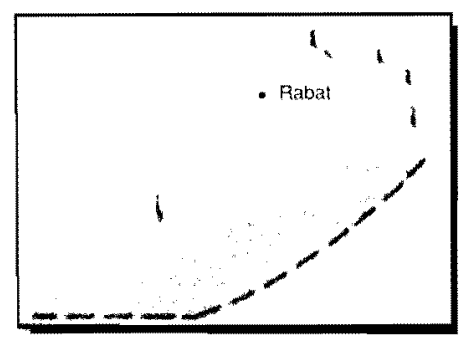

Morocco is renowned for its development of water-saving irrigation techniques in the absence of a major water source or extensive rainfall. Much of this expertise is unknown outside West Asia and North Africa. In contrast, Morocco lacks Asia's long experience in farmermanaged irrigation or, the more recent experience of the turnover of government systems to farmers. However, FMIS outside Morocco's command areas of ORMVAs (parastatal agencies in charge of agricultural development) command almost one third of the country's irrigated area. Including those systems within ORMVA's command, FMIS make up two-thirds of the irrigated surface of the country.
During 1991, the Institute, which operates a comparably smaller program here than in other countries, carried out the first phase of a project to provide irrigation advice to farmers in surface irrigation systems in Tadla. Researchers found that farmers who depend on the principal of "Robta" - small flooded basins — waste significant quantities of water, except when used in the advanced stages of cotton. Also, while farmers were able to determine their present crop water requirement, they proved unable to accurately anticipate the shift from a simpler, planned irrigation to a more flexible water delivery schedule.

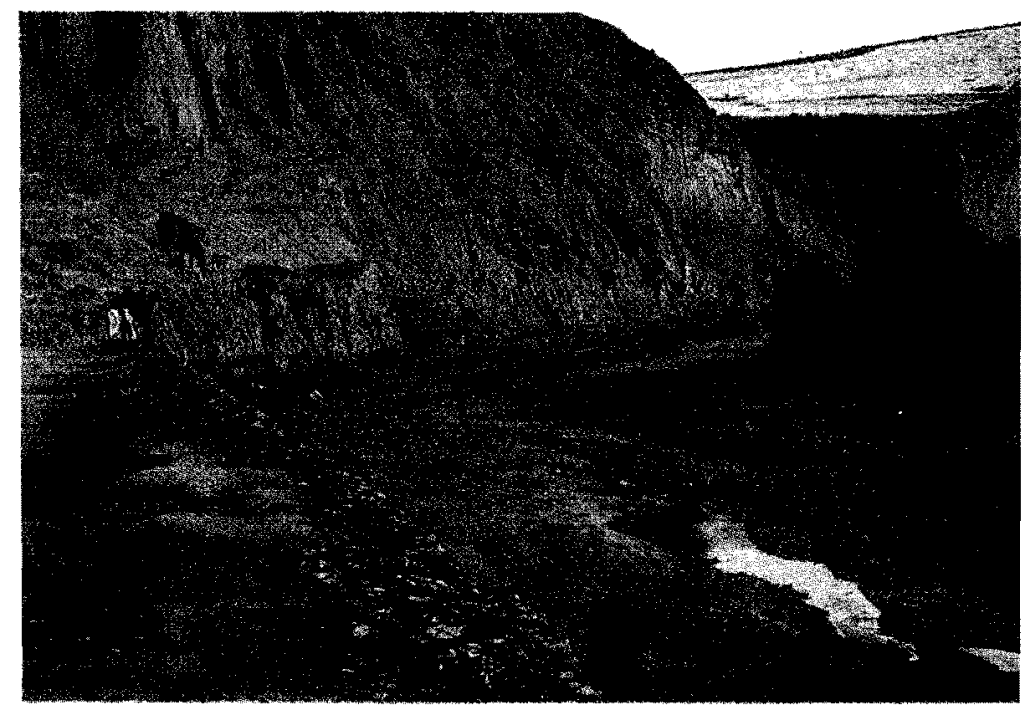

Morocco has centuries old traditional irrigation systems. 
Throughout the year, the Institute's staff in Morocco advised other IIMI country programs, in Pakistan and West Africa, and various institutions within Morocco. The staff also worked with the
Institute's research division in assessing the interaction of design and management of Morocco irrigation systems for a generic project of the same title.

\section{WEST AFRICA}

From Burkina Faso to Nigeria, West African governments are struggling to feed, clothe and care for a population that is growing far faster than the land can sustain. In the Sahel, people shift with the sands that each year spread the domain of the desert. In these countries, there is rarely any mention of a permanent balance of food, with imports racing ahead of production. In the humid tropics to the north, extremes of income further tip the balance toward volatility.

Irrigation won't solve the problem. But it will help. At present, irrigated lands make up less than 3 percent of the region's cultivated area, or about 1.7 million out of 61 million hectares. However, the extent of irrigated lands could be tripled, and if carefully managed, could provide a relatively large and steady source of food and income that planners can depend on and farmers can live by. Under crisis conditions, particularly in the Sahel, every additional crop grown on an additional hectare makes a difference.

Although more than two thirds of existing irrigation is already managed by farmers, it is generally accepted, however, that irrigation systems do not achieve their initial planned objectives. Performance of irrigation in Africa viewed in purely technical terms is comparable with irrigation in other parts of the world (rice yields of $5-6 \mathrm{t} / \mathrm{ha} /$ cycle are quite common). The difficulties are largely related to the combined effect of different socioeconomic factors.

It is in that context, that the Institute initiated a regional network for West Africa in 1988. Given the similarities of irrigation development and potentials in West Africa, the network is designed to provide vital links between Asia and the region and within the region itself, through research, training and information exchange. It is based on the concept of triage, i.e., it is designed to produce results in the shortest possible period of time.

In 1991, research began in Burkina Faso, where IIMI's Regional Representation is based, and in Niger and Nigeria. In 1993, research will begin in Mali. The research in these four countries will form the basis of the network that will eventually link and provide valuable inputs to the other countries of the Sahel and the humid tropical zones.

In 1991, in addition to coordinating and planning the regional research and training network, IIMI's regional representative produced the first issues of the quarterly West Africa Irrigation Network Newsletter in English and French. The response to the Newsletter was overwhelmingly positive. 


\section{Burkina Faso}

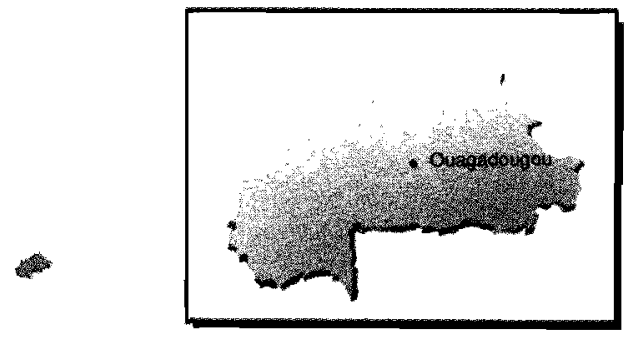

The potential of irrigation in West Africa is wellexemplified by Burkina Faso. Its population of nearly 9 million is currently growing at an annual rate of about 3 percent. Irrigated agriculture is estimated to cover about 16,000 ha, but the potential is estimated to be ten times that. The irrigation sector is confronted with a set of problems typical of the early stages of its development - low cropping intensities, farmers with little or no tradition in irrigated agriculture, personnel involved in irrigation system management who lack the requisite training and skills, multiple institutions which intervene in the sector with different priorities and preoccupations.

1991 saw the commencement of IIMI's program in Burkina Faso, aimed at improving the performance of small-scale, reservoir-based village irrigation schemes, common to the country. Six such irrigation schemes have been selected as research sites. During the year, staff began field research in two systems: the 24-year-old Mogtedo and the three-year-old Itenga schemes.

By the end of the year, staff had completed a socioeconomic and organizational profile of both systems, and had updated the information relating to their physical characteristics. Staff had also assessed system management practices through monitoring of water deliveries along the main canals and in sample distributary canals and had carried out water balance surveys in selected fields, to determine such factors as percolation and evapotranspiration rates. In the process, researchers had identified a number of shortcomings: weak farmers' organizations, a lack of management training among personnel, and the absence of reliable information related to the irrigation infrastructure (canal network, irrigated areas). In one case, an extensive topographical survey carried out by IIMI staff revealed that "unauthorized irrigation" in the head reaches alone amounts to 25 percent of the command area.

The research component of the program is complemented by training/professional development and information dissemination components. In November, as part of a new collaborative agreement with the Burkina Faso representation of the World Conservation Union (IUCN), the Institute produced a newsletter in

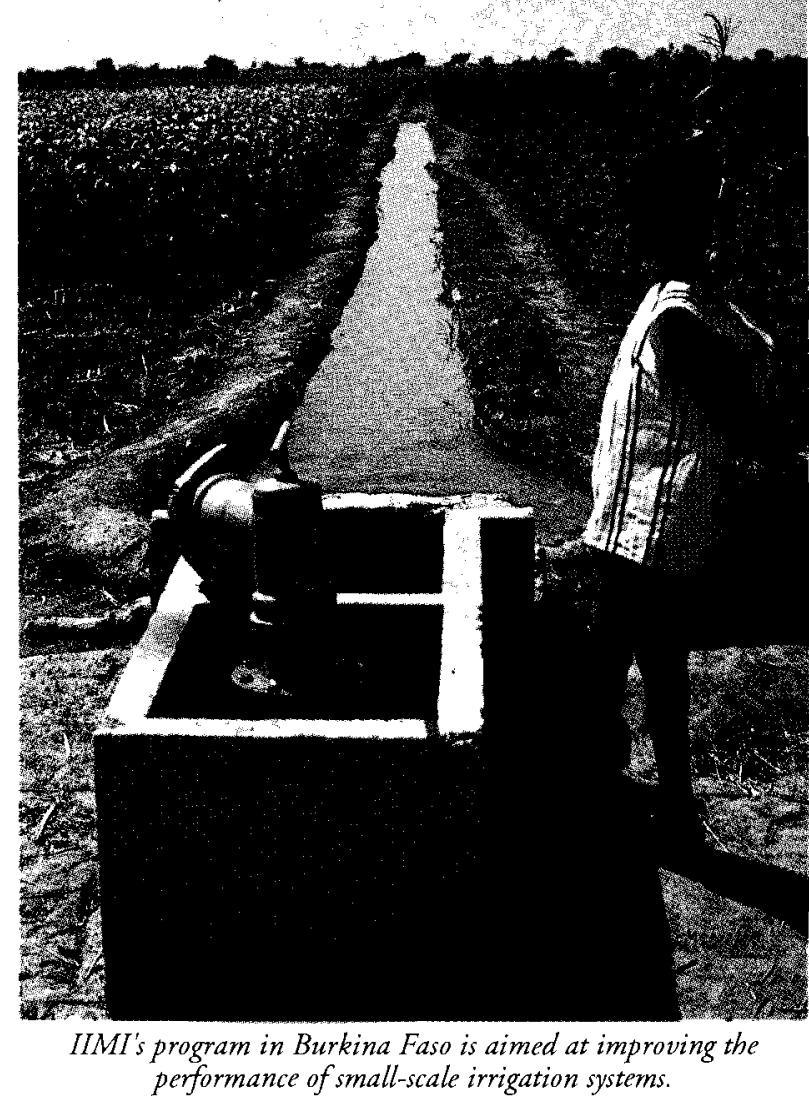


Moor, the most widely spoken national language. The issue featured irrigation and reforestation as well as presented the views of farmers in the Institute's two field sites. IIMI also collaborated with IUCN and the John-Paul II Foundation to coproduce a video film on water in the Sahel, part of which was filmed at IIMI field sites. The video highlights the benefits which can be obtained from proper water resources management.

\section{Niger}

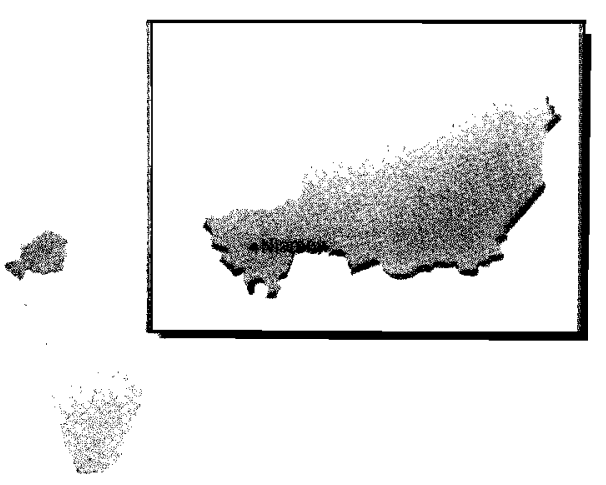

In the case of Niger, irrigation may represent the last stand against the spreading desert. Landlocked, $600 \mathrm{~km}$ from the sea, Niger is one of the hottest regions on earth. Only 12.5 percent of the land is potentially cultivable and only 2.5 percent is actually cultivated. The population of 7.2 million is growing at some 3.5 percent a year. Still, there is a potential for irrigating 270,000 ha against the present total of 81,000 ha. Most of this lies along several major sources of water including the Niger and Komadougou rivers, where irrigation is carried out with small-scale hand-lifting to large-scale pumping stations.

There are some 30 modern irrigation schemes along the Niger River covering over 6,700 ha. To date, farmer-management of larger-scale schemes has functioned well with the technical support of
ONAHA (a parastatal, financially independent institution which plays a decisive role in irrigation development).

State disengagement and the success of the Cooperative Movement in Niger are largely due to a favorable institutional context and a gradual introduction of formal contractual links among the different actors who play a role in irrigation management. However, the initial success of selfmanagement by the beneficiaries is threatened by difficult political and socioeconomic conditions. The legal status of the cooperatives is still awaiting finalization, the rural code is being reviewed, and low priced rice imports compete with local production.

In 1991, staff concluded a formal country agreement to work in Niger with diplomatic status, identified five experts and three technicians to be seconded from the government, hired three support staff and moved into IIMI offices. By the end of the year, preliminary work had been completed leading to the identification of three research sites along the Niger River, and the development of an accompanying research program. The work is scheduled to begin in early 1992. 


\section{NIGERIA}

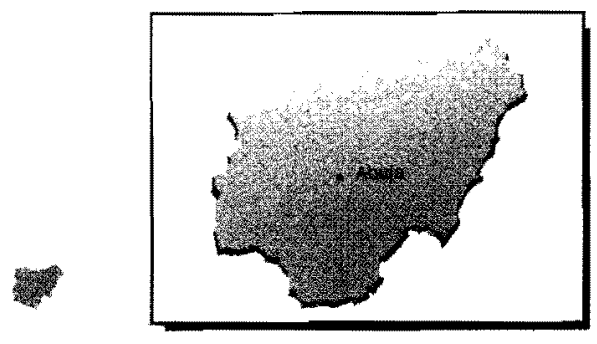

In the late 1960s, Nigeria was one of Africa's major exporters of food and was able to meet its own needs on a sustainable basis. But during the oil boom, agriculture was delegated less priority. By the late 1970 s when prices began to fall, Nigeria had become a major importer of food stuffs. Still, the severe drought of 1972-73 prompted the government to undertake water conservarion and utilization projects. In 1976, the government formed 11 river basin development authorities to undertake irrigation-related infrastructure and agriculture development.

In 1987, the government announced plans to privatize and commercialize public sector enterprises, including the 11 River Basin Development Authorities. Today, with some 1 million hectares of irrigated area -90 petcent under traditional irrigation systems and an estimated potential of 2 million hectares, the government is pursuing a twopronged development approach. First, existing irrigation agencies are being asked to become self-financing; this will involve the imposition of water charges, new institutional arrangements and greater participation of farmers in irrigation management.
At the same time, the government has undertaken to develop the remaining irrigated potential.

The Institute, in 1991, assisted the government to make this difficult transition. In particular, staff are working in the Kano River Irrigation Project, in collaboration with the Hadejia Jama ara River Basin Development Authority. Until 1987, the Kano River staff provided farmers with water, agricultural inputs, machinery for land preparation and marketing services. With the new policy, farmers must pay for all services, while the Authority is shifting to irrigation-related activities only.

During the year, staff collected information at three pilot sites on the socioeconomic status of farmers, crop coverage, water availability, the extent of existing farmers' organizations and the ability and willingness of farmers to pay water charges.

\section{Utilizing techniques from Nepal and} elsewhere, IIMI staff worked with the Authority to develop a procedure for the formation of the farmers' organizations, to create a legal basis for their existence, and to define the role they were

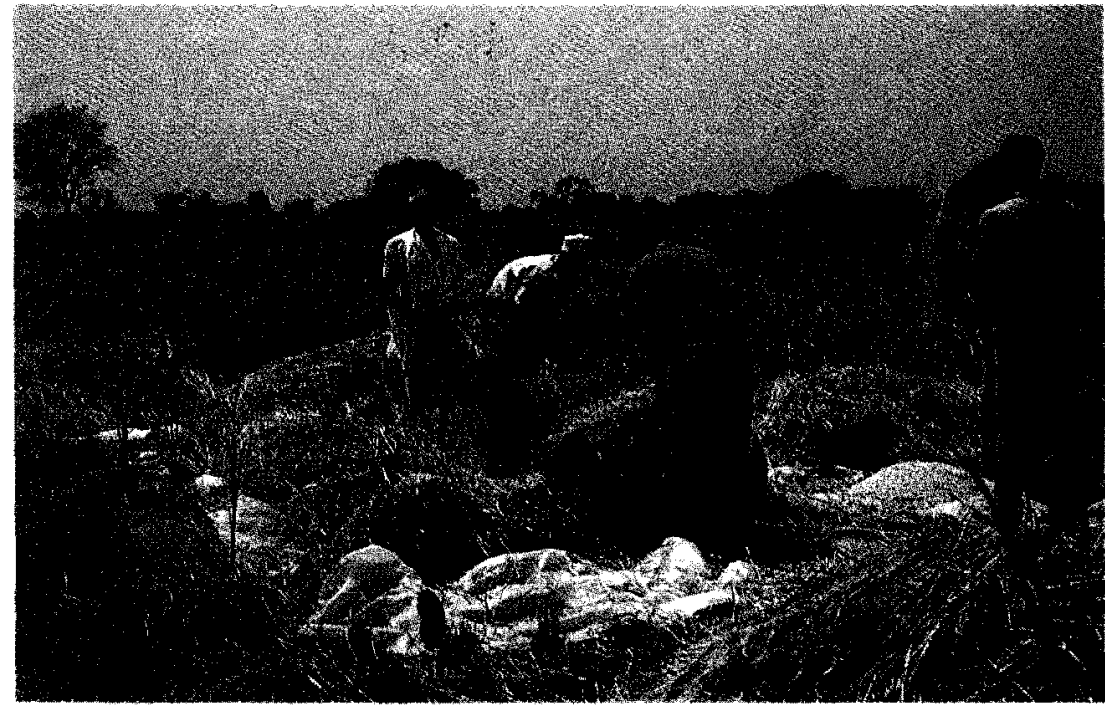

Better willation of existing imigation systems is necersary to meet Nigeria's future food needs. 
expected to play in water management. Staff also rationalized the fee collection procedures and the amounts to be assessed. This and other information will be documented for use in other systems in Nigeria, where agencies are struggling to adjust to their new role as commercial enterprises.

\section{Latin America}

The area under irrigated agriculture in Latin America is about 16 million hectares. The major irrigation countries of the region include Mexico, Brazil, Argentina, Chile, Peru, Cuba, Ecuador and Colombia. These countries account for almost 90 percent of the total irrigated area of the region. Although, in several countries, irrigation is concentrated on market crops rather than on staple cereal crops, there are substantial pockets like northeast Brazil, northwest Peru, and central Chile where irrigation plays an important role in food production.

The rationale for an IIMI program in the region lies mainly in the opportunities it offers in addressing generic irrigation management issues in an environment that is different from those usually encountered in Asia and Africa. These differences stem from levels of technology used as well as from a more prominent role of the nonpublic sector in the development and management of irrigation systems.

The first regional activity carried out by IIMI in Latin America was the organization of a symposium on irrigation management in 1990. During 1991, an international workshop on the performance of farmer-managed irrigation systems was held in Mendoza, Argentina. It was sponsored by the FMIS Network and organized jointly by IIMI and the Instituto Nacional de Ciencia y Técnica Hídricas (INCYTH), Argentina. This workshop provided an opportunity for strengthening understanding of the basic concepts and principles of performance evaluation and its role in the management of irrigation systems. It also brought together irrigation management experiences of Asia, Africa and Latin America, thus promoting the possibility of continuing dialogues and exchanges of experiences between Latin America and the countries of Asia and Africa.

To establish its program in Latin America, IIMI (with financial support from the Ford Foundation), fielded a two-man consultative mission to develop a workplan for the region. In the larter part of 1991, the mission visited six Latin American countries (Argentina, Brazil, Chile, Colombia, Ecuador and Mexico) and had discussions with many members of national irrigation departments and other government departments, research institutions, water users' associations and regional organizations.

The mission has identified several areas of research: these include the operational management of water deliveries, the management of transfer of responsibilities, methodologies for performance assessment, and the role of policy instruments. These research areas have been selected not only because of their individual importance but also because of their mutual interdependencies. Collaborative research activities in the region will be complemented by professional development and information exchange programs.

The report of the mission will serve as a basis for developing an IIMI Program in Latin America. 


\section{Training and Capacity Building}

In many developing countries, irrigation agencies administer rather than manage irrigation systems with an emphasis on following rules and procedures. What is most often needed is the strengthening of the organizations responsible for managing the systems, primarily through the development of the necessary human resources. The Institute's program of training and capacitybuilding has two principal components: strengthening national institutions and training of individual managers and policymakers.

The Institute's recently completed three-year training cycle in Malaysia, shows how IIMI endeavors to strengthen irrigation institutions.

At the end of 1989 , the Institute training staff, in close collaboration with the Department of Irrigation and Drainage (DID) in Malaysia, initiated the cycle with a Training Needs

Assessment. The assessment, conducted over 30 days, sought to identify factors affecting individual performance of 321 irrigation staff; and to provide a proposal for solutions, for example, fulfilling training needs or making organizational changes.

In Pebruary 1990, the resuiting evaluation was presented to 28 sentor manger and engineers. during a threeday worksop. 'This was then followed by ane-day volishop notober to discuss and oecide on organzaronal needs fo: implementing two training activities with the Institute's assistance The DID chose to focus on curricula for Engineers and Irrigation Overseers including definition of generai objectives, participants' level, time frame, contents and evaluation strategies.

In February 1991, staff developed the curricula and prepared basic training materials to support the exercises. Materials included slide and video presentations, charts, handouts, exercise sheets, flip charts and audio cassettes, which were derived from eight Institute publications and papers on topics ranging from farmer-managed systems to the role of engineers in irrigation systems; texts and videos from other organizations were also included.

From 22 April to 11 May 1991, the Institute used these training materials in the first exercise for Training-of-Trainers at the Continuing Education Center of the Universiti Pertanian Malaysia, in collaboration with the Irrigation Department and university staff. Fifteen university teachers and irrigation and agricultural trainers attended. From 15 to 25 October, the Department's Director General, Director of Projects and Deputy Director General and some 40 other senior officials met with the Institute's training staff to review organizational issues and the progress of the activities.

Last, from 26 October to November 6, the first two training activities were carried out by five Malaysian trainers from the university and the DID and were monitored by IIMI staff.

Participants developed a series of action plans, which will be monitored by the DID training staff, who will later provide feedback to the Sistitute. One of nany outcomes of the thee-year exercise was the developent of a Human Recumes Development on by the DID, the phan modes a systmatic training progran and a pefomance equation syster for personel.

Based on its success in Malaysia, the staff also initiated the same cycle for the Bangladesh Agriculcural Development Corporation. The exercise began wh a May assessment of 17 ? personnel. Staff returned to present the resuits to the Corporation's senior managers in September. In 1992, efforts will get underway to begin the cycle in Sudan.

Related to this effort, an International Training-of-Trainers Program was held in Kuala Lumpur in early November with participants from Indonesia, Malaysia and Thailand. 


\section{Indlvidaol Tralning}

In the area of Individual Training, IIMI hosted three fellowships and four scholarships during 1991. These included one doctoral candidate from Burkina Faso and four Master's Degree candidates - two each from Burkina Faso and Pakistan - and two research fellows from Burkina Faso (see Annex III).

\section{Collaboratlve Research fictivities}

Research collaboration with national partners is an excellent vehicle toward IIMI's goal of strengthening national capacities. Participating staff learn about field research firsthand and gain a greater benefit from the results. Collaborative studies are, therefore, a vital element in IIMI's training activities. In 1991, collaborative research activities were initiated in several countries including Pakistan, Burkina Faso, Niger and Sri Lanka, details of which are given in the boxes below.

In Pakistan, IIMI is participating in a nationwide effort to upgrade the country's irrigation research network and to strengthen the research capacity of the institutions concerned. IIMI's role in this project is to provide technical assistance to participating national research institutions. As part of this effort, IIMI is working closely with the International Waterlogging and Salinity Research Institute to enhance the research management skills of their staff.

\section{figreements}

Organization

\section{Barkina Faso}

International Union for Conservation of Nature and Natural Resources

\section{Nilger}

Government of Niger

\section{Higerla}

International Crop Research Institute for the Semi-Arid Tropics
For joint publication of a newsletter in the national language (Moor) which will address issues related to irrigation and the environment.

Memorandum of Agreement for Research Development Program on Irrigation Management in the farmer-managed irrigation systems of the Niger River

To collaborate in a research program with Hadejia Jama'ara River Basin Authority in Kano, Nigeria. 


\section{Research Contracts}

\section{Contract Title}

Pakdstan

Rapid Socioeconomic Survey of Sample Areas in the North-W/est Frontier Province (NWFP), as Part of the Crop-Based Irrigation Operations Project in NWFP.

\section{Phillppines}

Develop a Technical Training Manual for Use by the National Irrigation Administration.

Research/Intervention Project on People's Upliftment through Self-Help.

Pilot Intervention in Bicol for Organizational Development for Strengthening of Irrigation Associations and IA/NLA Partnership.

Research/Intervention Project Involving Information, Education and Communication Materials in Irrigation Management.

Extension of Water Measurement and Farm Productivity Study in the National Irrigation Systems in the Bicol Region.

Extension of Design Review of Communal Systems in Region VI.

Research/Intervention Plan 2 for Region VI: A WVSU-NIA Social Action Research Project.

Support Activities, Staff Training and Irrigation Associations' Intervention Training.

\section{Sri Lanka}

Study of Turnover and O\&M on Distributaries to Farmers' Organizations in Polonnaruwa District.

Study on Maximizing Profitability of Irrigated Agriculture in the Polonnaruwa District.

Study on Cost-Effective Irrigation Modernization Strategies.

Provide Training in Methodologies to IIMI Regional Offices and Field Staff.

\section{Research Institute}

Economic Development Corporation, Pakistan.

Mandala Agricultural Development Corporation, Philippines.

Central Mindanao University, Musuan, Bukidnon, Philippines.

Bicol University Development Foundation Inc., and Ateneo de Nagar University, Naga City, Philippines.

University of the Philippines in the Visayas, Iloilo City, Philippines.

Bicol University Development Foundation Inc., Philippines.

Central Philippine University, Iliolo City, Philippines.

West Visayas State University, Iliolo City, Philippines.

National Irrigation Administration, Philippines.

TEAMS (Pvt) Ltd., Sri Lanka.

Agriculture Industry Consultancy $\&$ Services (Pvt) Ltd., Sri Lanka.

Engineering Consultants Ltd., Sri Lanka.

Sri Lanka Institute of Development Administration Staff, Sri Lanka. 


\section{Workshops and Conferences}

Workshops and conferences and related institurional development activities are designed to contribute both to strengthening national irrigation research capacity and supporting the introduction of improved management and policymaking.

These workshops provide opportunities to exchange information between countries on new thinking and current experiences in the field of irrigation management.

In 1991, IIMI organized or co-organized 25 workshops and conferences in several countries. IIMI also participated in 27 workshops and conferences organized by other institutions. The details of these events are as follows:

\section{Workshops and Conferences Organlzed or Co-organlzed by IIrII}

Title

Future Directions for Irrigation Investments in Sri Lanka (co-organizer: IMPSA).

World Bank-IIMI Workshop.

Workshop on Financing İrrigation Services in the Philippines (co-organizers: IFPRI/NIA),

5th Annual Meeting of the Advisory Committee of the Network on Farmer-Managed Irrigation Systems.

Workshop on Training-of-Trainers in Collaboration with Universiti Pertanian Malaysia and Department of Irrigation and Drainage, Malaysia.

Training Needs Assessment at Bangladesh Agricultural Development Corporation.

Workshop on Irrigation Water Charges (co-sponsor:

Advisory Unit for Agricultural Corporations).

Workshop to Review the Inception Report of the Phase II of the Technical Assistance Study, Irrigation Management and Crop Diversification.

Training Seminar on Research Methods for Irrigation Management Research (co-organizer: Water and Land Management Institute, Bihar).

\begin{tabular}{|c|c|}
\hline Dates & Location \\
\hline $\begin{array}{l}24-25 \\
\text { January }\end{array}$ & $\begin{array}{l}\text { Colombo, } \\
\text { Sri Lanka. }\end{array}$ \\
\hline $\begin{array}{l}4-5 \\
\text { February }\end{array}$ & $\begin{array}{l}\text { Colombo, } \\
\text { Sri Ianka. }\end{array}$ \\
\hline $\begin{array}{l}1 \\
\text { March }\end{array}$ & $\begin{array}{l}\text { Manila, } \\
\text { Philippine }\end{array}$ \\
\hline $\begin{array}{l}12-14 \\
\text { March }\end{array}$ & $\begin{array}{l}\text { Manila, } \\
\text { Philippine }\end{array}$ \\
\hline $\begin{array}{l}22 \text { April - } \\
11 \text { May }\end{array}$ & $\begin{array}{l}\text { Perdang, } \\
\text { Malaysia. }\end{array}$ \\
\hline
\end{tabular}

26 May - Dhaka, 15 June Bangladesh.

29 May Khartoum, Sudan.

10-11 Hambantota, June Sri Lanka.

$\begin{array}{ll}\text { 11-14 } & \text { Bihar, } \\ \text { June } & \text { India. }\end{array}$


2nd Progress Review and Coordinating Workshop on Irrigation Management for Crop Diversification in Rice-Based Systems Research Network (co-sponsored by DGWRD and the Faculty of Agricultural Technology, Gadjah Mada University).

DSE/IIMI Workshop on Farmer-Managed Irrigation Systems.

Workshop to Deliver Training Needs Assessment Results to Top Management of Bangladesh Agricultural Development Corporation.

Regional Workshop on Research on Sustainable Agriculture (co-organizers: ICRISAT/IBSRAM)

Privatization of Irrigation Schemes in Sudan (co-organizers: Ministry of Agriculture/Ministry of Irrigation, Sudan and Arab Organization for Agricultural Development).

Workshop on Improving Management of Irrigation Systems Maintenance.

Applied Research for Increasing Irrigation Effectiveness and Crop Production (co-organizers: IRRI/BRRI).

Training Course on Rapid Rural Appraisal for Irrigated Agriculture (co-organizer: Sudan Gezira Board).

Round-Table Discussions and Workshops for Senior Managers of the Department of Irrigation and Drainage in Malaysia.

Accelerated Agricultural Production Project - Project Development Workshop.

Monitoring the Implementation of the Training Activities in Malaysia - Training of Irrigation Overseers.

DSE/IIMI Training and Dialogue Program - International Training-of-Trainers.

DSE/IIMI Workshop on New Trends and Policies in Irrigation Management.

Performance Measurement in Farmer-Managed Irrigation Systems (co-organizer: National Institute of Water and Technology).
9-12

September

Yogyakarta, Indonesia.
23 September - 11 October

28-30

September

30 September -2 October

6-7

October

8 October

8-9

October

8-20

October

15-25

October

23-25

October

26 October6 November

28 October6 November

4-7

November

12-15

November
Chiang Mai, Thailand.

Dhaka,

Bangladesh.

Bangkok,

Thailand.

Khartoum,

Sudan.

Colombo,

Sri Lanka.

Dhaka,

Bangladesh.

Wad Medani,

Sudan.

Kuala Lumpur, Malaysia.

Legaspi City, Philippines.

Kota Bharu, Malaysia.

Kuala Lumpur, Malaysia.

Colombo, Sri Lanka.

Mendoza, Argentina. 
Monitoring the Implementation of the Training Activities

$13-26$

Penang,

in Malaysia - Training of Irrigation Engineers.

November

Malaysia.

DSE/IIMI Workshop on Management Orientation

25-29

Bangkok,

in Irrigation Engineering Curricula.

November

Thailand.

\section{Selected Workshops and Conferences at which IIMI was Represented}

Irrigated Agriculture Sector Review (organizers: National

Irrigation Administration/World Bank).

International Symposium on Indus, the Lifeline of

Pakistan (organizer: Pakistan Council Research

Water Resources).

Irrigation Issues in Bangladesh (organizers: Rural

Development Academy/Human Resources Development

Program of Winrock International).

54th Meeting of the Technical Advisory Committee

(organizer: Consultative Group on International Agricultural

Research).

42nd International Executive Council of the International

Commission on Irrigation and Drainage

(organizer: International Commission on Irrigation Drainage)

Training Workshop on Farmer Participation in Irrigation

(organizer: Water and Land Management Institute,

Gujarat, India).

VIIth International Water Resources Association World

Congress on Water for Sustainable Development

"in the 21 st Century" (organizer: International Water

Resources Association).

Second Irrigation Management Policy Advisory Committee

Policy Workshop (organizer: Irrigation Management

Policy Support Activity Secretariat, Colombo, Sri Lanka).

Regional Workshop on Salt Water Intrusion Problem

(organizer: Pakistan Council Research Water Resources).

Irrigation Management in Asia (organizer: Agricultural

Productivity Organization).
26-27

February

2-7

March

11

March

$12-17$

March

14-21

April

28-30

April

Anand,

India.

13-18

May

Rabat,

Morocco.

17-19

May

Ahungalle,

Sri Lanka.

19-28

May

Lahore,

Pakistan.

18-20

June
Tokyo,

Japan. 
Irrigation Development Policies in the Sahelian Countries (organizer: Inter-State Commission for Prevention of Drought in Sahel and the Organization for Cooperation and Economic Development).

Comprehensive Water Resources Management

Policy Workshop (organizer: World Bank).

55th Meeting of the Technical Advisory Committee (organizer: Consultative Group on International Agricultural Research).

1991 Annual Convention of the Japanese Society of Irrigation, Drainage and Reclamation Engineering (organizer: Japanese Society of Irrigation, Drainage and Reclamation Engineering).

Third Irrigation Management Policy Advisory Committee Policy Workshop (organizer: Irrigation Management Policy Support Activity Secretariat, Colombo, Sri Lanka).

Common Property Conference (organizer: International Association for the Study of Common Property).

Use of Modern Irrigation Systems in Arab Countries

(organizer: Arab Organization for Agricultural Development).

Finance and Rural Development in West Africa (organizer: International Center for Cooperation in Agronomic Research Applied to Development).

11 th Annual General Meeting of the Panel of Experts on Environmental Management and Vector Control (organizer: Panel of Experts on Environmental Management and Vector Control).

56th Meeting of the Technical Advisory Committee (organizer: Consultative Group on International Agricultural Research).

CGIAR International Centers Week (organizer: Consultative Group on International Agricultural Research).

Gender Awareness Workshop (organizer: Consultative Group on International Agricultural Research).
$18-21$

June

Banjul,

Gambia.

$21-28$

June

Washington, USA.

$24-30$

June

Rome,

Italy.

$17-19$

Kochi,

July

Japan.

20-22

September

Habarana,

Sri Lanka.

26-29

September

Winnipeg,

Canada.

8-11

Kenitra,

October

Morocco.

21-25

October

Ouagadougou, Burkina Faso.

21-25

October

Kuala Lumpur, Malaysia.

21-27

October

Washington, USA.

28 October1 November

Washington,

USA.

1-2

November

Washington, USA. 
Consultative Workshop on Land and Water Resources

Development Policy Issues (organizer: Irrigation Management

Policy Support Activiry Secretariat, Colombo, Sri Lanka).

8th Afro-Asian Regional Conference on "Land and Water

Management in Afro-Asian Countries"

(organizer: International Commission on Irrigation

and Drainage).

Regional Seminar on Water Management Practices (organizer: Federation of Engineering Institutions of South and Central Asia).

Geographic Information Systems Workshop (organizer: International Development

Research Center, Canada).

8th Annual Irrigation and Drainage Meeting (organizer: World Bank).

\section{$15-16$}

November

Katunayake,

Sri Lanka.

$18-23$

November

Bangkok,

Thailand.

21-22

November

Dhaka,

Bangladesh.

28-29

November

New Delhi,

India.

9-16

December
Washington, USA.

\section{Information}

IIMI's Information Program supports two main elements of the Institute's strategy. First, the program publishes and disseminates reports of management innovations and research outputs. Second, it assists in strengthening national capacities and enhancing national efforts by distributing information to developing countries. The latter is increasingly done through national irrigation information systems.

As an operational support mechanism, the Information Program relates to all areas of the Institute. As an educative process, the Program is closely connected to training activities of an operational nature. Through its public relations and functions, the Information Program further disseminates news about the research programs. The program has three components: publications, communications and technical information services.

During 1991, the Institute published 16 new titles: these included 4 governance publications, 3 research publications, and 4 working papers and project reports. In addition, five newsletter issues were also produced and distributed: these included two issues of the FMIS Network Newsletter, one issue of the IMCD Research Network Newsletter, one issue of the West Africa Irrigation Network Newsletter and one issue of the IUCN/IIMI Newsletter (see Annex II). To lower costs and speed publication, the Institute has introduced desktop publishing.

\section{Ubrary and Docamentation}

In 1991, library holdings at headquarters increased to 8,504 items from the 6,504 in 1990 . The number of physical items amounts to 57 percent of the holdings, i.e., 4,819 physical volumes, while the remainder includes unpublished material and reprints of journals. The Library and Documentation unit also published Vol 3, Number 2 of the Irrigation Management Information Network, a database of selected literature on irrigation management published semiannually. 


\section{Finance and Administration}

During 1991, IIMI's income consisted of US $\$ 1.960$ million in unrestricted resources, US $\$ 0.772$ million in indirect cost recoveries and US $\$ 6.147$ in restricted support, to meet expenditures grossing US\$9.280 million. After allowing for indirect cost recoveries, the Institute's net resources for 1991 were US\$8.107 million, against net expenditures of US $\$ 8.508$ million (See Figures 1\&2).

Even though the accounting policy adopted by IIMI in the previous years was not to recognize depreciation, consequent to IIMI's admission to the Consultative Group on International Agricultural Research (CGIAR) in 1991, the accounting policy adopted by IIMI was changed to fall in line with the guidelines issued by the CGIAR which required International Agricultural Research Centers to recognize depreciation as a charge against the operating income of the year. Accordingly, the total depreciation charge applicable to IIMI for 1991 amounted to
US $\$ 407,150$. Reduction of IIMI's retained operating surplus enabled the deficit of US\$401,050, which was the direct result of the depreciation charge of US $\$ 407,150$, to be adjusted. Had IIMI not provided for depreciation, IIMI would have ended the year with a modest operating surplus of US\$6,100. IIMI's cash assets at the end of 1991 were US $\$ 2,270,125$. Over US $\$ 9,800,000$ of new restricted grants to fund IIMI projects had been approved during the year.

Arrangements for a permanent headquarters building in Colombo were finalized with the Government of Sri Lanka and IIMI moved into its permanent headquarters in December 1991.

At the close of 1991, IIMI had 30 senior internationally recruited staff. Some 102 national and international professionals were engaged in IIMI's research, training, and information activities in headquarters and overseas units. IIMI's total staff numbered 297, more than half of them based outside Sri Lanka (See Figure 3 in Annex IV).

\section{Unrestricted and Restricted Sapport - 199}

Donor

1991 Grant US\$

Onrestulcted Sapport

CIDA

262,824

Ford Foundation

450,000

Japan

232,261

Netherlands - Staff Secondment

USAID

World Bank

Bank Interest

Sundry Income 
Unrestricted and Restricted Support - (continued)

\section{Ratricted sapport}

ADB

AFDB

$A F D B$

$\mathrm{AFDB}$

AFDB

AUSTRALLA

$\mathrm{BMZ}$

DSE/ZEL

DSE/ZEL

FORD

FORD

FORD

FORD

FORD

FORD

FORD

FORD

FORD

FORD

FORD

FORD

FRANCE

FRANCE

FRANCE

FRANCE
Proposed Management Improvements to Undertake

Crop-Based Irrigation Operations in NWFP, Pakistan

268,102

Technical Assistance in Sri Lanka: Phase II

209,365

Irrigation Management Development in Burkina Faso

129,455

Irrigation Management Development in Niger

146,040

Support for IIMI Research Programs in Africa (carry over 1990)

83,052

Support for IIMI Research Programs in Africa

118,785

AIDAB Assistance for Collaboration between IIMI and Australian Institutions

24,837

Enhancement of Research on Irrigation and Drainage Technology (IPTRID)

158,860

Workshop on New Trends and Policies in Irrigation Management - 1990

Workshop on New Trends and Policies in Irrigation Management - 1991

35,000

Strengthening the Capacity of Institutions and Personnel in Bangladesh to Manage Irrigation Systems

127,430

BUET Workshop on Performance Evaluation of Flood Control,

Irrigation and Drainage Projects in Bangladesh

Collaborative Research in India to Strengthen the Capacity of

Indian Institutions to Improve Irrigation Systems

6,758

59,259

175,180

24,910

1,096

12,055

338,225

Support for an Irrigation Management Program in Sudan

61,175

37,920

16,163

68,887

156,999

38,041

Trust Fund for Staff Secondment 1990

42,096 
Unrestricted and Restricted Support - (continued)

\begin{tabular}{|c|c|c|}
\hline Donor & Project & 991 Grant US\$ \\
\hline IDRC & Support for Workshop on FMIS Performance & 17,500 \\
\hline IFAD/BMZ & Assistance to Farmer-Managed Irrigation Systems: Phase I & 96,139 \\
\hline IFAD/BMZ & Assistance to Farmer Managed Irrigation Systems: Phase II & 157,568 \\
\hline IFAD & $\begin{array}{l}\text { IIMI Participation in an IFAD Mission on Non-Indus } \\
\text { Basin Irrigation Systems in Pakistan }\end{array}$ & 2,926 \\
\hline JAPAN & Support for Irrigation System Performance Assessment Program & 199,074 \\
\hline JICA & Support for Staff Secondment & 30,000 \\
\hline JICA & Research on Irrigation Investment Trends in Sri Lanka & 1,526 \\
\hline NETHERLANDS & Performance Assessment Diagnosis & 105,977 \\
\hline NETHERLANDS & Applied Research on Waterlogging and Salinity in Pakistan & 527,532 \\
\hline ROCKEFELLER & $\begin{array}{l}\text { IIMI/IRRI Collaborative Research on Rice-Based Farming } \\
\text { Systems in the Philippines, Indonesia and Bangladesh }\end{array}$ & 73,370 \\
\hline ROCKEFELLER & Grant for Performance and Research Direction in Bangladesh & 449,450 \\
\hline TARC & Studies on Improvement of Water Management of Cascade Tank Systems & 2,360 \\
\hline USAID & $\begin{array}{l}\text { Program to Support the Irrigation Objectives of the } \\
\text { USAID Supported AAPP in the Philippines }\end{array}$ & 900,582 \\
\hline USAID & $\begin{array}{l}\text { Collaborative Research in India to Strengthen the Capacity of } \\
\text { Indian Institutions to Improve Irrigation Systems }\end{array}$ & 165,866 \\
\hline USAID & $\begin{array}{l}\text { Irrigation Management Policy Support Activity (IMPSA) } \\
\text { in Sri Lanka: Phase I }\end{array}$ & 147,721 \\
\hline USAID & Irrigation Management Policy Support Activity (IMPSA) in Sri Lanka: Phase II & 49,210 \\
\hline USAID & Irrigation Systems Management Project in Sri Lanka (ISM) & 145,744 \\
\hline USAID & Irrigation Support Project for Asia and the Near East (ISPAN) & 40,548 \\
\hline USAID & Action Research Program in Banganga Irrigation System in Nepal & 106,712 \\
\hline USAID & $\begin{array}{l}\text { Strengthening National Capacity to Improve the Performance } \\
\text { of Irrigation Systems in Pakistan }\end{array}$ & 187,840 \\
\hline USAID & Improving the Capacity of Water Management Research in Pakistan & 207,694 \\
\hline WORLD BANK & Appointment of a Senior Water Management Advisor to the Sudan Gezira Boarc & ird 180,637 \\
\hline \multirow[t]{3}{*}{ WORLD BANK } & IIMI/World Bank Workshop & 5,000 \\
\hline & Subtotal & $6,146,764$ \\
\hline & Total & $8,106,724$ \\
\hline
\end{tabular}

See ANNEX I for an explanation of the projects listed above. 


\section{CONSOLIDATED STATEMENT OF FINANCIAL POSITION (BALANCE SHEET) AS OF 31 DECEMBER 1991}

IIMI's consolidated balance sheet as of 31 December 1991 reflects the fact that during the year 1991, the accounting policy relating to the recognition of depreciation was changed. The policy adopted in the previous years was not to recognize depreciation. Based on the guidelines issued by the CGIAR, as from 1 January 1991 CGIAR Centers are to recognize depreciation on all nonexpendable assets as a charge against operating income of the year and to transfer an amount equivalent to the depreciation charged from the investment in nonexpendable assets account to a capital fund account. According to the CGIAR Guidelines, the accumulated depreciation on fixed assets for the period prior to 1 January 1991 was transferred from the investment in nonexpendable assets account to the accumulated depreciation account.

1991 / US\$

\section{CURRENT ASSETS}

Cash and Short-Term Deposits

Receivables

Deposits and Pre-Payments

Inventories

Total Current Assets

$$
\begin{array}{r}
2,270,125 \\
831,628 \\
313,615 \\
49,623 \\
3,464,991
\end{array}
$$

1990 / US\$

$1,165,692$

$1,165,112$

281,626

78,222

$2,690,652$

$1,103,466$

$3,794,118$

$5,302,125$

Total Assets

\section{CURRENT LIABILITIES}

Funds Applicable to Succeeding Years

Other Payables and Accruals

$$
\begin{array}{r}
1,437,069 \\
963,151 \\
2,400,220
\end{array}
$$

$1,428,783$

388,946

$1,817,729$

98,687

11,446

Severance \& Gratuity Benefits

LONG-TERM LIABILITIES

Program-Related Investment Loan -

Ford Foundation, New York

$1,014,121$

NIL

\section{FUND BALANCES}

Funds Representing Investment in

Property, Plant and Equipment

Reserves

Accumulated Operating Surplus

Capital Fund

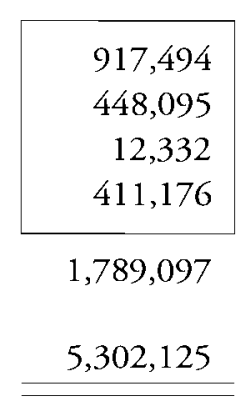

$1,103,466$

448,095

413,382

NIL

Total Fund Balances

$1,789,097$

$1,964,943$

TOTAL LIABILITIES AND FUND BALANCES

$3,794,118$

Source: Extracted from the 1991 Auditors' Report. 
Figure 1

Net Income, $1984-91$

(US\$ millions)

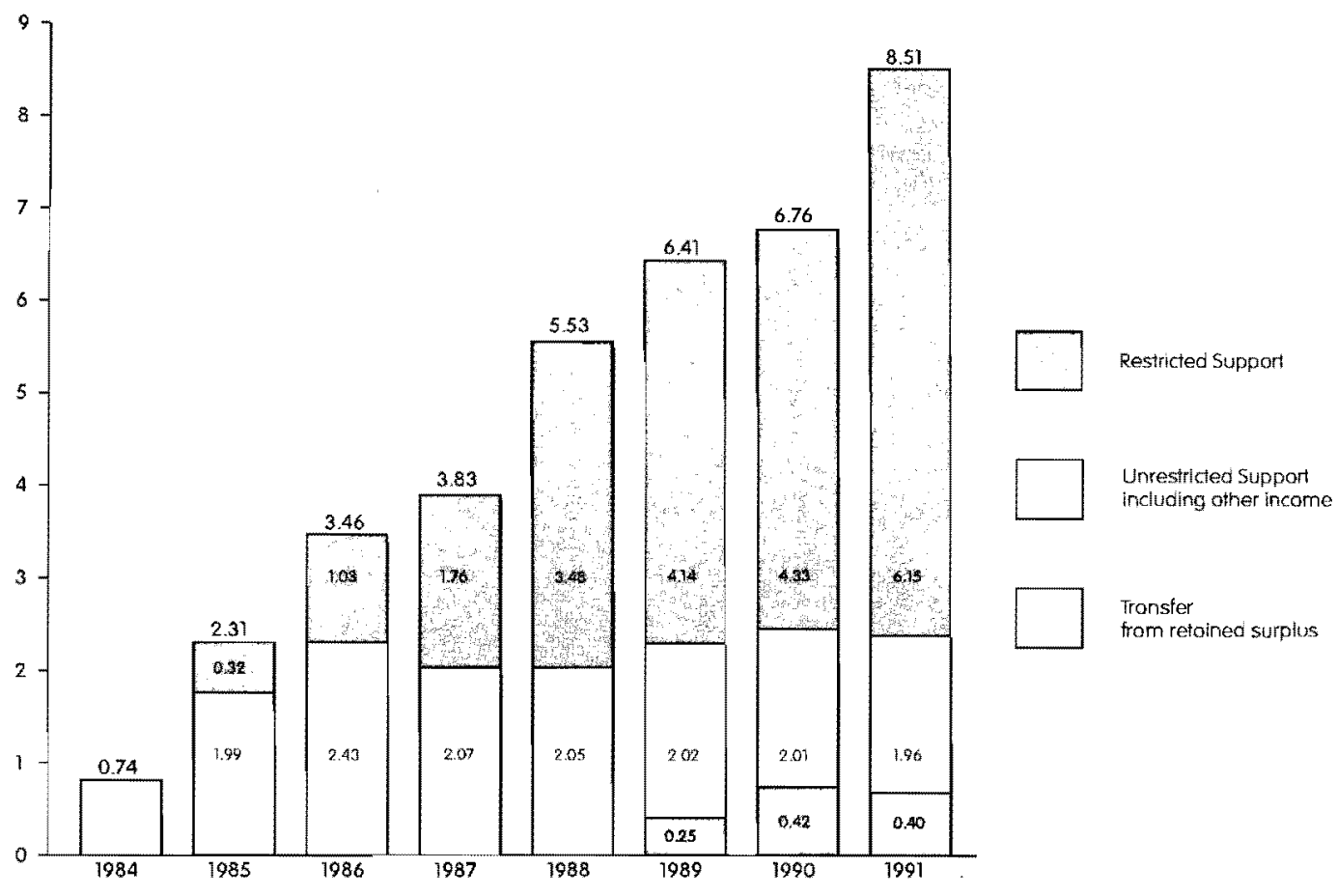

Figure 2

Net Expenditure, 1991

(US\$ millions)

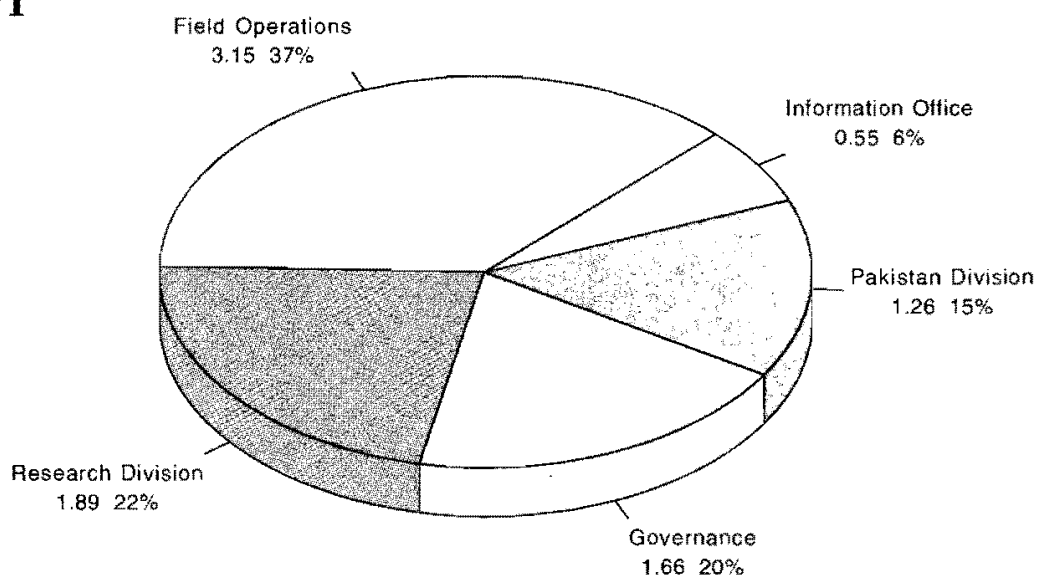




\section{ANNEX I \\ RESTRICTED PROJECTS 1991}

\begin{tabular}{|c|c|c|c|c|c|}
\hline Project & Donor & $\begin{array}{l}\text { Pledged } \\
\text { amount* }\end{array}$ & Duration & $\begin{array}{c}\text { Cumulative } \\
\text { expenditure } \\
\text { to } \\
31 / 12 / 1990 \\
\text { US\$ }\end{array}$ & $\begin{array}{c}\text { Expenditure } \\
1991 \\
\text { US\$ }\end{array}$ \\
\hline
\end{tabular}

\section{PAKISTAN}

To identify and assist in the implementation of proposed management improvements for undertaking crop-based irrigation operations in the North-West Frontier Province.

\section{SRI LANKA TA PHASE II}

To strengthen the long-term viability of irrigation systems and to optimize the use of existing land, water and infrastructure resources through implementing, refining and evaluating management recommendations developed under Phase I in the processes af: system management, operation and maintenance, system rehabilitation and improvement; and institutional strengthening of irrigation agencies and farmers organizations, with particular attention given to tequirements for crop diversification.

\section{BURKINA FASO}

To support a program of research, professional development and information exchange to improve the performance of small-scale reservoir-based village irrigation schemes.

\section{NIGER}

To supporr a program of research, professional development and information exchange to improve the performance of small-scale reservoir-based village irrigation schemes.

\section{IIMI PROGRAM IN AFRICA}

To support IIMI research programs in West Africa, Morocco and Sudan.

\section{COLLABORATION WITH AUSTRALIAN INSTITUTIONS}

Assistance of the Australian International Development Assistance Board (AIDAB) for collaboration between IIMI and Australian Institutions.

\section{ASIAN DEVELOP- $\quad 1,000,000 \quad 36$ months MENT BANK}

\section{ASLAN}

750,000

27 months

209,365

268,102

(2)

\section{BANK}

AFRICAN

DEVELOPMENT

BANK

\section{AFRICAN \\ DEVELOPMENT \\ BANK}

\footnotetext{
*In US dollars unless otherwise stated.
}

\section{AFRICAN \\ DEVELOPMENTT \\ BANK}

AUSTRALIA

\section{$575,000 \quad 36$ months $\quad 311,954$}

201,837 
ANNEX I (continued)

\section{ENHANCEMENT OF RESEARCH ON \\ IRRIGATION AND DRAINAGE TECHNOLOGY (IPTRID)}

To provide a framework for collaborative action for assessment of technology Research and Development (R\&D) needs; assist developing countries and external supporting agencies in identifying priorities in $R \& D$ related to irrigation and drainage technology; support the formulation of R\&D policies and programs in line with sectoral plans; facilitate training and exchange of information and experience.

\section{DSE COLLABORATION}

DSE/ZEL

DSE/IIMI Workshop on New Trends and Policies in Irrigation Management, 1990 and 1991.

\section{BANGLADESH}

To strengthen the capacity of relevant institutions and personnel in Bangladesh to manage

irrigation systems and irrigation development.

\section{BANGLADESH UNIVERSITY OF ENGINEERING TECHNOLOGY (BUET) PERFORMANCE WORKSHOP, BANGLADESH}

Dhaka

FORD

FOUNDATION

Dhaka

Aimed at performance evaluation of Hood control, irrigation, and drainage projects in Bangladesh as part of BUET and Bangladesh Water Development Board pilot program to improve management.

\section{INDIA}

To explore and initiate collaborative projects between IIMI and Indian institutions through research, professional development, and information exchange. This work is designed to strengthen the capacity of Indian institutions to contribute to the improvement of irrigation systems.

\section{IIMI MISSION TO EGYPT}

Exploratory mission to assess the possibilicy of establishing a collaborative research and development program in Egypt.

\section{IRRIGATION MANAGEMENT FOR LATIN AMERICA}

Support to design and initiate irrigation programs in Latin America FOUNDATION
900,000

36 months

158,860

\section{FORD}

Delhi

FORD FOUNDATTON Cairo

FORD FOUNDATION 300,000 24 months
200,000

67 months

129,334 
ANNEX I (continued)

\section{NIGERIA}

Support for an irrigation management program in Nigeria.

\section{LOCALLY MANAGED IRRIGATIION SYSTEMS}

To prepare publications based on a review of literature and experience related to Farmer-Managed Irrigation Systems

\section{PROFESSIONAL DEVELOPMENT}

To support postdoctoral research on irrigationrelated settlement planning, and predoctoral research to develop a model that would simulate the functioning of a small tank irrigation system.

STUDY OF THE IRRIGATION PROGRAM OF THE AGRICULTURAL DEVELOPMENT BANK OF NEPAL (ADBN)

Support for a study of the irrigation program of $A D B N$.

\section{SUDAN}

Support for an irrigation management program in Sudan

\section{SUPPORT FOR COLLABORATIVE ACTIVTTY IN NEPAL}

Support for IIMI to assist the Government of Nepal in developing participatory programs for irrigation development.

\section{SUPPORT FOR RESEARCH ON FARMER CONTRIBUTIONS TO IRRIGATION COSTS}

IIMI consultancy expenses - grant to the Faculry of Economics and Business Administration of the Kesetsart Universiry.

TRAINING IN RAPID RURAL APPRAISAL (RRA) WORKHSOP

Support for training in Rapid Rural Appraisal.
FORD

425,000

24 months

175,180

FOUNDATION

New York

FORD

FOUNDATION

35,000

14 months

10,090

24,910

New York

FORD

FOUNDATION

46,300

49 months

45,204

1,096

New York

FORD

FOUNDATION

New York

FORD

478,000

24 months

338,225

FOUNDATION

New York

FORD

FOUNDATION

405,000

36 months

New York

FORD

FOUNDATION

3,925

24 months

0

Bangkok

FORD

FOUNDATION

37,920

6 months

37,920 


\section{ANNEX I (continued)}

\section{MOUNTAIN WORKSHOP}

Support for a regional workshop on design issues in small-scale irtigation in mountain environments.

\section{SIMULATION MODEL APPLICATIONS AT KIRINDI OYA}

To support research on main canal operations using a mathematical simulation model produced on microcomputer.

\section{SUPPORT FOR MOROCCO} AND WEST AFRICA

Support for activities undertaken by IIMT in Morocco and West Africa.

\section{TRUST FUND FOR STAFF SECONDMENT}

Government of France -

trust fund for staff secondment.

\section{MENDOZA WORKSHOP}

To support the participation of one participant each from South Asia and the Middle East and two participants from Latin America.

\section{ASSISTANCE TO FARMER-MANAGED IRRIGATION SYSTEMS - PHASE I}

To support a research program on assistance to farmer-managed irrigation systems, including maintaining a research network and newsletter.

\section{ASSISTANCE TO FARMER-MANAGED} IRRIGATION SYSTEMS - PHASE II

For continuing a research program in farmer-managed irrigation systems.

\section{PAKISTAN}

To participate in an IFAD general idenrification mission on Non- Indus Basin Itrigation Systems Utilized by Small Farmers.
FORD FOUNDATION

New York

FRANCE

FRANCE

FRANCE

IDRC

IFAD

$\mathrm{BMZ}$

IFAD

IFAD

US $\$ 150,000$ DM 970,000)
U\$ $\$ 120,000$ DM 940,000
36 months

619,186

96,139 
ANNEX I (continued)

IIMI/JICA STAFF SECONDMENT

Support for staff secondment.

\section{IRRIGATION INVESTMENT TRENDS}

JICA

2,000

12 months

Research on alternative investment opportunities in Sri Lanka.

\section{ICID - PERFORMANCE ASSESSMENT DIAGNOSIS}

NE'THERLANDS

DFL

15 months

48,092

105,977

To undertake a joint project with the International Institute for Land Reclamation and Improvement and International Institure for Hydraulic and Environmental Engineering, on relationships between irrigation design and management and resulting effects on performance of irrigation systems.

\section{WATERLOGGING AND SALINITY PROJECT, PAKISTAN}

Support to IIMI Pakistan to implement, in collaboration with national agencies, a program of applied research on waterlogging and salinity. Research will focus on irrigation strategies designed to prevent waterlogging and salinity.

\section{IIMI/IRRI COLLABORATION ON IRRIGATION MANAGEMENT FOR RICE-BASED FARMING SYSTEMS}

To conduct collaborative research with IRRI on the problems of water management in irrigation systems devoted to rice-based farming systems in the Philippines, Indonesia, and Bangladesh.

\section{GRANT FOR PERFORMANCE AND RESEARCH DIRECTION, BANGLADESH}

To rest irrigation management approaches that improve coordination between irrigation agencies and farmers in Bangladesh; to initiate a major effort to quantify measures of irrigation performance; and to expand IIMI's capacity for multidisciplinaty research.

TROPICAL AGRICULTURE RESEARCH CENTER (TARC)

Studies on Improvement of Water Management of Cascade Tank Systems.
NETHERLANDS

DFL $4,009,000$

60 months

625,899

527,532

ROCKEFELLER

$1,200,000$

56 months

$1,126,630$

73,370 
ANNEX I (continued)

\section{ACCELERATED AGRICULTURAL PRODUCTION PROJECT (AAPP) PHILIPPINES}

Program to support the irrigation objectives of the USAID supported AAPP in the Philippines.

\section{COLLABORATIVE RESEARCH IN INDIA}

To explore and initiate collaborative projects between IIMI and Indian institutions through research, professional development and exchange of information. This work is designed to strengthen the capacity of Indian institutions to contribute to the improvement of irrigation systems.

\section{IRRIGATION MANAGEMENT POLICY} SUPPORT ACTIVTTY (IMPSA) PHASE I, SRI LANKA

\section{USAID}

Washington

USAID

India

500,000

42 months

138,263

165,866

Project aimed at supporting the policy initiatives of the Government of Sri Lanka in the irrigation sector.

IRRIGATION MANAGEMENT POLICY SUPPORT ACTIVITY (IMPSA) PHASE II, SRI LANKA

Project aimed at supporting the policy initiatives of the Government of Sri Lanka in the irrigation sector.

\section{IRRIGATION SYSTEMS MANAGEMENT PROJECT (ISMP), SRI LANKA}

USAID

Sri Lanka

To assist USAID's Irrigation Systems Management Project through the development and implementation of research on key irrigation management questions, and to strengthen Sri Lanka's national capacity for irrigation management research. This work will build on IIMI's collaborative relationships with Sri Lankan irrigation-related research institutions and agencies.

\section{IRRIGATION SUPPORT PROJECT FOR ASIA AND THE NEAR EAST (ISPAN)}

To increase IIMI's capacity to develop more effective training and professional development programs.

\section{IRRIGATION IN BANGANGA, NEPAL}

To provide support for IIMI's action research program with the Department of Irrigation of the Government of Nepal in the Banganga Irrigation System.
USAID

Asia and Near

East Bureau
139,615

10 months

49,210
$460,000 \quad 48$ months

419,452

40,548 
ANNEX I (continued)

\section{INSTITUTIONAL DEVELOPMENT SUPPORT, IIMI PAKISTAN}

To support IIMI Pakistan's efforts to strengthen Pakistan's national capacity to improve the performance of irrigation systems through management innovations.

\section{IRRIGATION SYSTEMS} MANAGEMENT PROJECT

To improve the capaciry and relevancy of water management research in Pakistan.

Support for the appointment of a senior water management advisor to the Sudan Geriza Board under a World Bank-assisted rehabilitation project.

\section{IIMI/WORLD BANK WORKSHOP}

5,000

2 days

Sudanese Pounds 567,400

US\$ 395,500
WORLD BANK

USAID

Pakistan

WORLD

USAID

BANK

\section{SENIOR WATER MANAGEMENT ADVISOR, SUDAN GEZIRA BOARD}

24 months

85,653

180,637

To support direa costs of the parricipation of IIMI's field operations staff at a workshop for the

World Bank to familiarize itself with the activities and programs of IIML.

\section{Total}

* In US dollars unless otherwise stated. 


\section{ANNEX II \\ PUBLICATIONS 1991}

\section{GENERAL PUBLICATIONS}

International Irrigation Management Institute. External program and management review of the International Irrigation Management Institute. A report by the external review panel. Colombo, Sri Lanka: International Irrigation Management Institute. 116p. (March). ISBN-92-9090-139-X

International Irrigation Management Institute. 1992 Program \& Budget. Colombo, Sri Lanka: The Institute. 80p. (September).

\section{SERIALS}

International Irrigation Management Institure. A selected bibliography on irrigation management (Documents entered in the Irrigation Management Information Network database in 1989). Vol. 3. No. 2. Colombo, Sri Lanka: The Institute. 128p. (August). ISSN-1015-1680

\section{PERIODICALS}

International Irrigation Management Institute. Annual Report 1990. Colombo, Sri Lanka: The Institure. 60p. (September). ISSN-1017-5954

International Irrigation Management Institute. IIMI Review. Vol. 5. No. 1. Colombo, Sri Lanka: The Institute. 36p. (November). ISSN-1012-831X

\section{NEWSLETTERS}

International Irrigarion Management Institute. FMIS. No. 8. Newsletter of the Farmer-Managed Irrigation Systems Network. Colombo, Sri Lanka: The Institute. 24p. (February). ISSN-1012-988X

International Irrigation Management Institute. FMIS. No. 9. Newsletter of the Farmer-Managed Irrigation Systems Network. Colombo, Sri Lanka: The Institute. 16p. (September). ISSN-1012-988X

Institut International du Management de l'Irrigation. Bulletin du Réseau Irrigation Afrique de l'Ouest. No. 001. Burkina Faso, West Africa. 48p. (July). ISSN-1017-110X

Institut International du Management de l'irrigation. Union Mondiale pour la Nature, Bulletin NAMANEGDZANGA. No. 001. Burkina Faso, West Africa. 8p. (November).

International Irrigation Management Institute. IMCD News. Vol. 2. No. 1. Newsletter of the Research Network for Irrigation Management for Crop Diversification in Rice-Based Systems. Colombo, Sri Lanka: The Institute. 16p. (October). ISSN-1016-7927

\section{TECHNICAL PAPERS}

Vermillion, D. L. The turnover and self-management of irrigation institutions in developing countries. A discussion paper for a new program of the International Irrigation Management Institute. Colombo, Sri Lanka: International Irrigation Management Institute. 52p. (June).

\section{BOOKS}

Small, Leslie; Carruthers, Ian. Farmer financed irrigation. The economics of reform. Cambridge, New York: Cambridge University Press and International Irrigation Management Institute. 248p. (October).

ISBN-0-521-38073 
ANNEX II (continued)

\section{RESEARCH PAPERS}

Aluwihare, P.B.; Kikuchi, Masao. Irrigation investment trends in Sri Lanka: New construction and beyond. Colombo, Sri Lanka: International Irrigation Management Institute. 108p. (October). ISBN-92-9090-137-3

\section{COUNTRY PAPERS}

\section{Sri Lanka}

Dayaratne, M.H.S. A review of alternative strategies for improving farmer-managed irrigation systems in Sri Lanka. Colombo, Sri Lanka: International Irrigation Management Institute. 104p. (IIMI Country Paper - Sri Lanka No. 7). (June). ISBN-92-9090-136-5

\section{WORKING PAPERS}

Dayaratne, M.H.S.; Moragoda, Ranjini. An assessment of the village tank rehabilitation program of the Freedom From Hunger Campaign Board in Anuradhapura District. Colombo, Sri Lanka: International Irrigation Management Institute. 48p. (Working paper No. 20). (July). ISBN-92-9090-138-1

\section{PROJECT REPORTS}

International Irrigation Management Institute. Inception report on the Phase II Study (TA 1480 SRI): Irrigation Management and Crop Diversification. Colombo, Sri Lanka: The Institute. 154p. (July).

\section{PUBLICATIONS BY IIMI STAFF IN OUTSIDE JOURNALS, CONFERENCE PROCEEDINGS, ETC.}

Abernethy, C.L. and C.M. Miranda. Crop diversification in rice-based irrigation systems. Paper presented at the 7 th Afro-Asian Regional Conference of the International Commission for Irrigation and Drainage, Bangkok, Thailand, 18-23 November 1991.7p.

Abernethy, C.L. Canal lining: Techniques and benefits. Paper presented at the 11 th Annual Meeting of the Panel of Experts on Environmental Management for Vector Control, Kuala Lumpur, 21-25 October 1991. 14p.

Amarasekera, N. Environmental impact assessment of the Kirindi Oya Irrigation and Settlement Project, Sri Lanka. ESCAP Environment News, 9(2):12-14.

Ansari, N. and P. Pradhan (Eds.) Assistance to farmer-managed irrigation systems: Experiences from Nepal. Papers presented at the seminar on Improving Farmer-Managed Irrigation Systems: Experiences of Different Agencies and Organizations, 27 June 1990. Ministry of Water Resources, Department of Irrigation, Kathmandu, Nepal.

Bhatti, M.A.; F.E. Schulze and G. Levine. Yield measurement of irrigation performance in Pakistan. Irrigation and Drainage Systems, 5(2):183-190.

Bhurta, M.N.; M. Latif and J.W. Kijne. A study of water distribution from a branch to distributary canals: A case study of Gugera Branch, Punjab, Pakistan. Irrigation and Drainage Systems, 5(3):229-247.

Fernando, N. Tcchnological options in irrigated agriculturc for the furure. Economic Review, Sri Lanka, $(11 \& 12): 19-21 ; 54$. 
Lenton, Roberto L. Irrigation management strategies for the 21st century. Paper presented at the round table discussion on Water Strategies for the 21st Century: Guiding Ideas and Tendencies, 7th World Congress on Water Resources, International Water Resources Association, Rabat, Morocco, 13-18 May 1991. 10p.

Lenton, Roberto L. Problems and prospects in irrigation management in developing countries, with special emphasis on performance monitoring. Paper presented at the Annual Convention of the Japanese Society of Irrigation, Drainage and Reclamation Engineering, Kochi, Japan, 17-19 July 1991. 11p.

Merrey, D.J. Irrigation management institutions in Sri Lanka. Economic Review (special issue on "Irrigation in the Year 2000"), Sri Lanka, (11 \& 12):13-15;64.

Merrey, D.J. Reform in irrigation management systems in Sri Lanka: Farmer burden or farmer opportunity? Paper presented at the Research Colloquium of the Institure of Fundamental Studies (Kandy School of Science), Kandy, Sri Lanka, 2 October 1991. 15p.

Merrey, D.J. Book review - "Transforming a bureaucracy: The experience of the Philippine National Irrigation Administration," edited by Frances F. Korten and Robert Y. Siy Jr. Public Administration and Development, 11(1):89-90.

Svendsen, M. Sources of future growth in Indian irrigated agriculture. In Meinzen-Dick, R. and M. Svendsen, (Eds.) Future directions for Indian irrigation research and policy issues. Washington D.C., USA: International Food Policy Research Institute. pp. 42-68.

Valera, A. Farmer-managed irrigation systems: Its significance and effective government assistance. In Proceeding of the National Irrigation Policy Exercise Workshop, sponsored by the Department of Agriculture, Ministry of Agriculture, His Majesty's Royal Government of Bhutan, 'Thimpu, Bhutan, 25-31 October 1991.

Valera, A. and C.R. Panabokke. Irrigation management issues affecting clayey soil management for non-rice crop production in rice-based systems. In Pushparaha, E.; C.R. Elliot and R.N. Leslie (Eds.) The management of lowland clayey soils after rice in Asia. Bangkok, Thailand: International Board for Soil Research and Managemen (IBSRAM Proceedings no.11).

Vermillion, D.L. Farmer-level irrigation management in private and public systems in Indonesia: Distribution rules and exceptions. In farm level irrigation water management: Report of a study meeting in Lahore, Pakistan, 7-18 February 1989. Tokyo, Japan: Asian Productivity Organization. pp. 41-64.

Vermillion, D.L. The transition to self-managing irrigation institutions in developing countries. Paper presented at the Panel Session on Water Common Property Systems I, Common Property Conference, University of Manitoba, Winnipeg, Canada, 26-29 September 1991.25p.

Wijayaratna, C.M. Irrigation management in Asia. In Asian Productivity Organization, Management of irrigatio facilities in Asia and the Pacific. Report of APO Multi-Country Study Mission on Management of Irrigation Facilities, 18-28 June 1991. Tokyo, Japan: Asian Productivity Organization. pp. 23-76.

\section{IIMI-REI ATED PUBI.ICATIONS}

Panabokke, C.R. Irrigated agriculture in the year 2000. Economic Review, Sri Lanka, (11\&12):3-6;37.

Yoder, R Assistance to farmer-managed irrigation systems: Experience from WECS/IIMI/FORD Action Research Project in Indrawathi Watershed Basin. In Ansari, N. and P. Pradhan (Eds.), Assistance to farmermanaged irrigation systems: Experiences from Nepal. Paper presented at the seminar on Improving FarmerManaged Irrigation Systems: Experiences of different agencies and organizations, 27 June 1990: Ministry of Water Resources, Department of Irrigation. pp 51-70. 
ANNEX III

FELLOWSHIPS AND SCHOLARSHIPS 1991

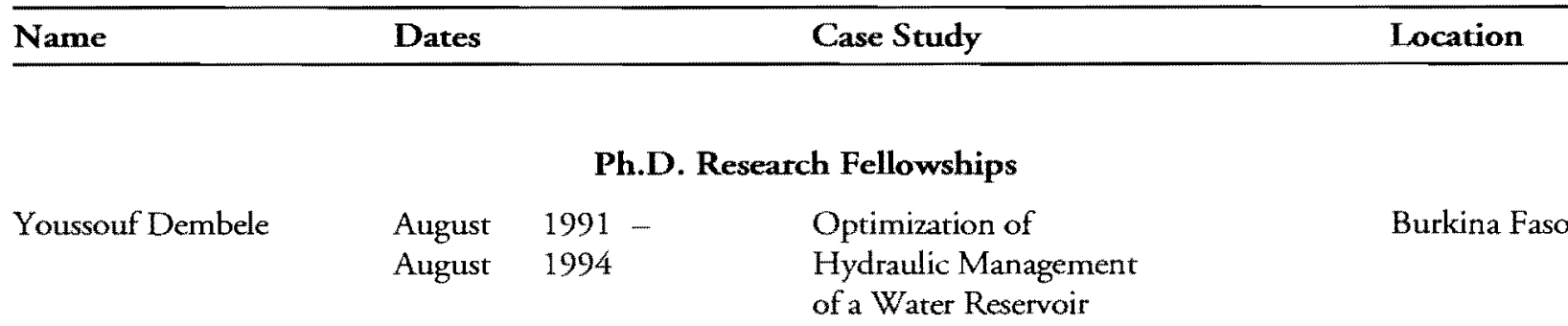

\section{Master's Degree Scholarships}

Amadou Keita

Amadou Allahoury

and

Casper van der Feltz

Andre $\mathrm{Da}$

Kalilou Diakite
December 1990 -

November 1991

November 1991 -

June

1992

October 1990 April 1991
Hydraulic Functioning of Irrigated

Areas: the Case of Mogtedo

Motivating Low-Intensity

Use of the Itenga Irrigated Area

During the Off-Season

Waterlogging and Salinity

Pakistan
Burkina Faso

Burkina Faso

\section{Other Fellowships}

November 1990 -

February 1992

Contribution to a Diagnostic-

Analysis of Two Hydraulic

Schemes for Agriculture

in Burkina Faso

November 1990 -

September 1991
Burkina Faso

Burkina Faso
Contribution to a Diagnostic-

Analysis of Two Hydraulic Schemes

for Agriculture in Burkina Faso 


\section{ANNEX IV \\ IIMI SENIOR STAFF 1991}

(The country, in the case of internationally recruited staff, is given in italics)

\section{OFFICE OF \\ THE DIRECTOR GENERAL}

Lenton, Roberto - Argentina

Director General

Daudrumez, Wendy

Special Assistant to the Ditector General

Nugawela, Dewaki

Executive Secretary (from March)

\section{RESEARCH DIVISION}

Mohtadullah, Khalid - Pakistan

Director, Research (from May)

Abernethy, Charles - United Kingdom

Senior Technical Advisor

Amarasekera, Nalini

Research Associate

Franca, Zenete - Brazil

Training Specialist

Hemakumara, H.M.

Research Officer

Itakura, Jun - Japan

Junior Seconded International Staff

Member (seconded from Tropical

Agriculture Research Centre, Ibaraki,

Japan) (from August)

Karunasena, H.A.

Research Associate

Kuruppuarachehi, Tilak

Research Associate

Manor, Shaul - Israel

Senior Irrigation Specialist

Miranda, Senen - The Philippines

Senior Irrigation Specialist (transferred to

Pakistan in May)

Murray-Rust, Hammond --

United Kingdom

Senior Irrigation Specialist

Mutukumarana, $P$.

Asst. to the Training Specialist (from

Ocrober)
Nijman, Charles The Netherlands

Associate Experr

Rey, Jacques - France

Associate Ittigation Specialist (from

February)

Sally, Hilmy - Sri Lanka

Irrigation Management and Engineering

Specialist (transferred to Burkina Faso in

April)

Samad, Madar

Assistant to the Director for Research (from June)

Schulze, Ernst - The Netherlands

Senior Technical Adviser (from July to

September)

Svendsen, Mark ..... USA

Research Fellow ${ }^{1}$

Valera, Alfredo - The Philippines

Irrigation Specialist (transferred to Nepal in

August)

Vermillion, Douglas - USA

Irrigation Specialist

Wolter, Hans - Germany

Irrigation Specialist ${ }^{2}$ (from April)

\section{FIELD OPERATIONS DIVISION}

Abeywickrema, Nanda - Sri Lanka

Director, Field Operations

Rarnayake, Ranjit

Assistant to the Director, Field Operations

\section{Bangladesh}

Parker, Donald - USA

Head, Bangladesh Field Operations

Hakim, M.A.

Associate Researcher (Seconded from Rural

Development Academy, Bogra,

Bangladesh)

Rahman, Abdur

Administrative Officer

\section{Burkina Faso}

Legoupil, Jean-Claude - France

Regional Representative, West Africa Fiel

Operations

Pouya, Andre-Marie

Information/Communicarion Specialist

Sally, Hilmy - Sri Lankaz

Irrigation Specialist and Project Leader, Burkina Faso (from April)

\section{Morocco}

Verdier, Jean -. France

Head, Morocco Field Operations

\section{Nepal}

Pradhan, Prachanda - Nepal

Head, Nepal Field Operarions (rransferre to Nigeria in August)

Valera, Alfredo - The Philippines

Head, Nepal Field Operations (from August)

Dutga, K.C.

Research Officer

Rayamajhi, Udaya

Administrative Officer

Shrestha, S.R.

Office Manager

\section{Niger}

Lonsway, Kurt - USA

Irrigation Specialist and Project Leader, Niger (from June)

\section{Nigeria}

Pradhan, Prachanda - Nepat

Irrigation Specialist and Project Leadet, Nigeria (from August)

Abubakar, A.R.

Research Officer

Olanrewaju, M.S.

Administrative Assistant 


\section{ANNEX IV (continued)}

Oyedepo, F.D.

Research Assistant

Sondangi, A.I.

Reseatch Assistant

\section{Philippines}

Wijayaratna, Chandrasekara, M. Sri Lanka

Head, Philippines Field Operations

Cablayan, D.

Research Associate

Elegado ${ }_{7}$ J A.

Research Assistant

Maglinao, Amado

Associate Researcher, IMMI-IRRI Project

PCARRD, Los Baños, Laguna

Manangan, Celso

Accounts and Administrative Officer

Marino, Ma Delia

Rescarch Assistant

Pintor, E.M.

Research Associate

\section{Sri Lanka}

Merrey, Douglas - USA

Head, Sri Lanka Field Operations

Aluwihare, Parakrama

Research Officer

Ariyaratne, B.R.

Research Officer

Brewer, Jeffrey - USA

Social Scientist (from December)

Ekanayake, Ratnasiri

Reseatch Officer

Hemakeerthi, K.A.

Research Officer

Jinapala, $K$.

Research Officer

Karunasena, H.A.

Research Associate

Kikuchi, Masao - Japan

Irrigation Specialist (until April)

Perera, L.R.

Research Officer
Sakthivadivel, Ramaswamy - India

Senior Irrigation Specialist

Samarakoon, Darshana

Administrative Officer

Somaratne, P.G

Research Officer

Upasena, W.J.J.

Research Office

Vithana, Chulawansa

Research Officer (from January)

\section{Sudan}

Shafique, Muhammad S. - Pakistan

Head, Sudan Field Operacions

Haq, Azharul - Bangladesh

Senior Water Management Advisor

\section{PAKISTAN DIVISION}

Schulze, Ernst - The Netherlands

Director (until June)

Kijne, Jacob W. - The Netherlands

Director (from.June)

Afaq, Rana Mohammad

Irrigation Engineer

Anwar, Haroon

General Manager,

Finance and Administration

Babar, Khurshid

Field Research Engineer

Badruddin, Mohammad

IIMI Pakistan Associate

Bandaragoda, Jayatissa -.... Sri Lanka

Senior Management Specialist

Bhatti, M. Akhtar

Principal Irrigation Engineer

Garces-Restrepo, Carlos - Colombia Irrigation Engineer (from April)

Habib, Zaigham

Systems Analyst

Haider, Sayed

Daniyal Accountant

Hussain, Irfan

Field Research Engineer
Khan, Hakeem

Field Research Engineer

Kuper, Marcel - The Netherlands

Associate Expert (from May)

Miranda, Senen - The Philippines

Senior Irrigation Specialist (from May)

Rehman, Saeed-ur

Senior Field Research Economist

Safdar, Ahmed Salecm

Field Research Engineer

Saleem, Mohammad

Field Research Social Scientist

Sendhu, Faiz Hanif

Senior Field Research Hydrologist

Shahid, Bagh Ali

Principal Irrigation Engineer

Strosse, Pierre - France

Agricultural Economist (from May)

Van Waijjen, Erik - The Netherlands

Associate Expert (from July)

Vander Velde, Edward J - USA

Irrigation Specialist

Zaman, Waheed-uz

Senior Field Research Engineer

\section{INFORMATION OFFICE}

O'Kelly, Francis - Ireland

Head, Information (until July)

Lenahan, James - United Kingdom

Head, Information (from September)

De Silva, Ramya

Documentalist

Fernando, K. Nimal A.

Chief Production Editor

Karunatatne, D.C.

Artist/Cartographer (from January)

Kurukulasuriya, Kingsley

Editor

Rabindranath, Susila

Press Officer (from February)

Somasundaram, Vasumathy

Administrative Officer 


\section{ANNEX IV (continued)}

Sri-Nammuni, Shanthi

Assistant Librarian

Sufian, A.C.M.

Producrion Manager

Van Eyck, David

Distriburion Manager

Yapa, N.U.

Head Librarian

\section{PROJECT DEVELOPMENT OFFICE}

Fuchs-Carsch, Marian - USA

Project Development Officer

Blok, Sharmini

Asst. Project Development Officer (from April)
FINANCE AND ADMINISTRATION DIVISION

Goodman, Daniel C. Jr. - USA

Director, Finance and Administration

Abayasekara, Mohan

Travel and Conference Coordinator

Abeysekera, Laksiri

Controller

Abeyesekera, Fred

Personnel Manager

Bahar, Omar

Personnel Officer

Ekanayake, Somasiri

Assistant Accountant

Halvirige, Gamini

Senior Accountant
Nanayakkara, Charith

Computer Services Manager

(from September)

Perera, K.S.C.

Maintenance Engineer

Samaraweera, Daya

Manager, Administrative Services

Weerasekera, Shanthi

Manager, Office Support Sysrems

Wettasinghe, Udaya

Budget Officer

'Based at IFPRI, under IIMI-IFPRI

Collaborative Program

${ }^{2}$ Based at IPTRID (on secondment from IIMI)

Figure 3

\section{Composition of IIMI Staff}

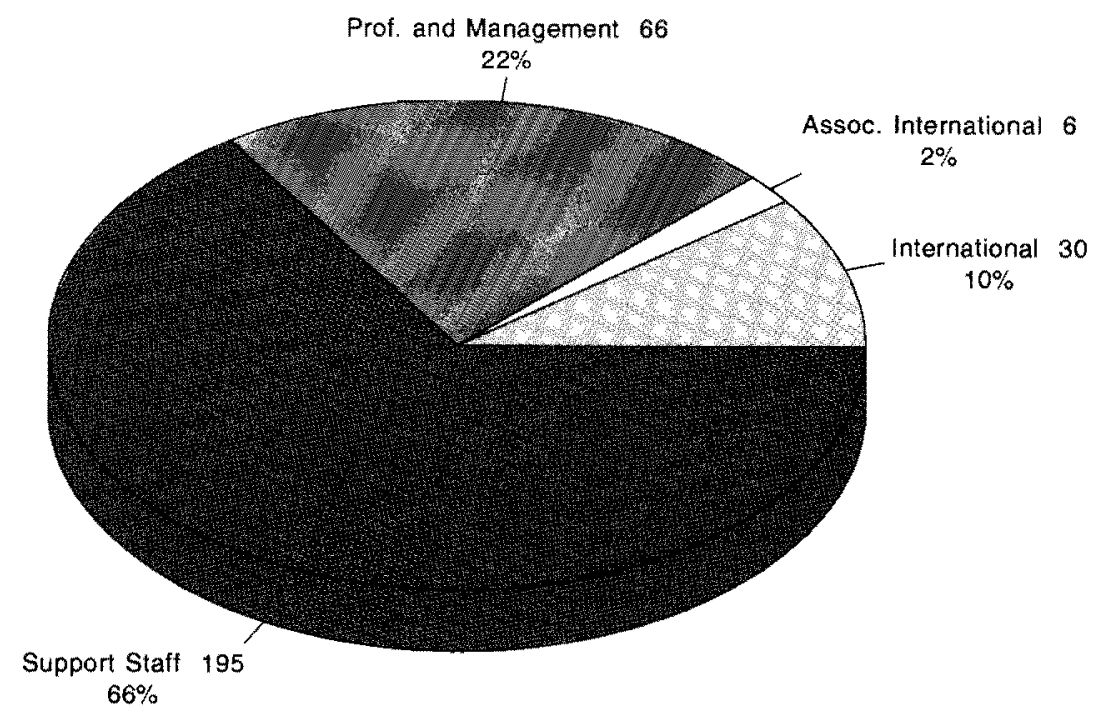

Total $=297$ 


\section{Research Division}

Mr. Adriza

Sri Lanka

Sri Lanka

Dr. S. Amunugama

Ing. A. Bertranou

Prof. D. Constable

Prof. A.A. Kampfraath

Prof. K.M. Kyi

Prof. G. Levine

Mr. B. Maier

Mr. P. Mutukumarana

Mr. R. Pochat
Sri Lanka and

Malaysia

Latin America

Bangladesh and

Sri Lanka .

Philippines and

Sri Lanka

Sri Lanka

U.S.A.

Sri Lanka

Sri Lanka
To analyze irrigation performance data collected by Prof. Kyi and his collaborators.

To translate documents from French to English for the Research Division.

To develop an IIMI Strategy and Workplan for Latin America.

To review IIMI reports on management control and management training of irrigation institutions.

To provide editorial assistance to a research publication and to assist training staff in the Workshop for Senior Managers at BADC in Bangladesh (to be held from 28-30 September 1992).

To complete reports on organizational dynamics studies in the Philippines and Sri Lanka.

To prepare Performance Program material.

To assist with data collection for a case study on the Management Transfer of the Columbia River Basin Project.

To develop training materials for the training of engineers, overseers and senior personnel in the Department of Irrigation and Drainage, Malaysia.

To review achievements and proposals concerning the simulation modeling project. 
ANNEX V (continued)

Dr. P.S. Rao

Mr. J.P. Sauvagere

Ir. F.E. Schulze

Dr. D. Seckler

Mr. K.J. Shepherd

Ms. R. Sooriyaarachchi

Dr. R.D. Wanigaratne

Dr. H.L. Angeles
Malaysia

Sri Lanka

Latin America

Sri Lanka

Sri Lanka and Australia

Sri Lanka

Sri Lanka
To assist the training staff in:

(a) a 3-week program for Training-ofTrainers in Malaysia (April-May 1991); (b) a 3-week Training Needs Assessment Program for BADC staff in Bangladesh (May-June 1991);

(c) a 3-day Workshop for senior managers of BADC to Deliver TNA Results (September 1991); and (d) Five training activities in Malaysia including three workshops for senior managers (October-November 1991); and the implementation of Management Training for Engineers and Irrigation Overseers.

To assist the Training Specialist.

To review achievements and make proposals concerning the simulation modeling project.

To develop an IIMI Strategy and Workplan for Latin America.

To assist in planning the 1992

Performance Program Activity.

To review various IIMI proposals and reports related to irrigation privatization, to prepare a case study on SelfManagement in South Australia, and to suggest ideas for collaboration with IIMI.

To rewrite statistical programs to analyze research data sets.

To funcrion as a resource person for the IIMI/DSE workshop on Trends and Policies in Irrigation Management for Senior Policymakers in South East Asia.

\section{Field Operations Division}

Philippines
To coordinate and supervise research activities of the irrigation component of the Accelerated Agricultural Production Project. 
ANNEX V (continued)

Mr. B. Bagadion

Mr. H.G. Farbrother

Dr. E. Ndiaye

Ms. A. Oyedotun

Dr. C.R. Panabokke

Dr. S.P.F. Senaratne

Dr. D. Taylor

Ms. N. Gijsen

Prof. G. Levine
Nigeria

Sudan

Sri Lanka

Nigeria

Sri Lanka

India

Sri Lanka

\section{Pakistan Division}

Pakistan

Pakistan

Pakistan
To discuss with the relevant staff of the Kano River Project the process of farmer involvement in irrigation management and to observe present operation and maintenance aspects of the Project.

To prepare a paper for the workshop on Privatization of Irrigation Schemes in Sudan.

To assist with planning and data analysis activities under Phase II of the ADBsupported work in Kirindi Oya.

To facilitate the finalization of the Memorandum of Agreement to be signed between the Federal Ministry of Water Resources in Nigeria and IIMI.

To plan and coordinate meetings for the Consultative Committee and to contribute to the Project on Irrigation Management and Crop Diversification.

To train field observers in collecting management-oriented data under the India-IIMI Program.

To formulate a methodology for analyzing the benefits and costs of management innovations being tested in Kirindi Oya and Walawe.

To write a report on Mechanisms for Coping with Salinity and Waterlogging Problems.

To advise on the applications of geoinformation systems for IIMI's research in Pakistan.

To advise on the implementation of three ongoing programs, and to conduct a "Retreat" with senior staff of the Punjab Irrigarion Department. 
ANNEX V (continued)

\section{Information Office}

Dr. A. K. Biswas

Mr. J. Colmey

Mr. B.H. Hemapriya

Mr. R. Lamb

Mr. C.S. Ranasinghe

Dr. B. Lynch

Mr. R. Bhatia

Dr. C. Francy

Mr. K. Fussing

Dr. W. Gormbley

Ms. J. Joshi

Mr. S. Lee
United Kingdom

Sri Lanka

Sri Lanka

Sri Lanka

Sri Lanka

\section{Project Development Office}

Sri Lanka
Sri Lanka

Sri Lanka

Sri Lanka

U.S.A.

Sri Lanka

Sri Lanka
To supply articles for the "IIMI Review,"

To design photograph albums.

To provide editorial assistance to the "IIMI Review."

To finalize all outstanding issues on the "Annual Report" and the "IIMI Review."

To copyedit and proofread "Irrigation Decision-Making Processes and Conditions."

To prepare a report that defines a research program on Women and Irrigation.

\section{Director General's Office/Finance and Administration}

To install a computer network in the Accounts Department.

To design and prepare a prototype of an administrative procedures manual.

To complete the design for the interior and furniture for the public areas of the IIMI headquarters building.

To prepare a report on Post-Secondary Educational Benefits.

To assist Finance and Administration write an administrative procedures manual.

To provide recommendations for the serting up of a local area network system for IIMI headquarters. 


\section{ACRONYMS AND SYMBOLS}

$\mathrm{ADB}$

$A F D B$

APO

BADC

BMZ

BRRI

CIDA

CGLAR

DGWRD

DID

DSE

ESCAP

FMIS

IA

IBSRAM

ICRISAT

ICRISAT-WASIP

IDRC

IFAD

IFPRI

IMCD

IMPSA

IPTRID

IRRI

JICA

NIA

NWFP

O\&M

ONAHA

ORMVA

PCARRD

TARC

TEAMS

TNA

USAID

WECS

WVSU-NLA

ZEL

ha

$\mathrm{t}$
Asian Development Bank

African Development Bank

Asian Productivity Organization

Bangladesh Agricultural Development Corporation

Bundesministerium für Wirtshaftliche Zussamenarbeit (Germany)

Bangladesh Rice Research Institute

Canadian International Development Agency

Consultative Group on International Agricultural Research

Directorate General of Water Resources Development (Indonesia)

Department of Irrigation and Drainage (Malaysia)

Deutsche Stiftung für Internationale Entwicklung (Germany)

Economic and Social Commission for Asia and the Pacific (United Nations)

Farmer-Managed Irrigation Systems

Irrigators' Association (The Philippines)

International Board for Soil Research and Management

International Crops Research Institute for the Semiarid Tropics

ICRISAT — West African Sorghum Improvement Program (Nigeria)

International Development Research Centre (Canada)

International Fund for Agricultural Development

International Food Policy Research Institute

Irrigation Management for Crop Diversification

Irrigation Management Policy Support Activity (Sri Lanka)

International Programme for Technology Research in Irrigation and Drainage

International Rice Research Institute

Japan International Cooperation Agency

National Irrigation Administration (The Philippines)

North-West Frontier Province

Operations and Maintenance

Office National des Aménagements Hydro-Agricoles

Office Régional de Mise en Valeur Agricole

Philippines Council for Agriculture, Forestry and Natural Resources Research and Development

Tropical Agricultural Research Centre (Japan)

Technology Evaluation and Management Services (Pvt.) Lrd. (Sri Lanka)

Training Needs Assessment

United States Agency for International Development

Water and Energy Commission Secretariat (Nepal)

West Visayas State University — National Irrigation Administration

Food and Agricultural Centre (ZEL)

hectare(s)

ton(s) 


\section{IIMI ADDRESSES}

\section{HEADQUARTERS}

127, Sunil Mawarha

Pelawatte via Colombo

Sti Lanka

$\begin{array}{ll}\text { Telephone } & :(94-1) 567404 \text { (8 lines) } \\ \text { Telex } & : 22318 \text { or } 22907 \\ & \text { IIMIHQ CE } \\ \text { Fax } & :(94-1) 566854 \\ \text { E-Mail } & : \text { CGNET: IIMT } \\ & (157 . \text { CGI 129) or } \\ & \text { Internet: IIMI } \\ & \text { @CGNET.COM } \\ \text { POBox } & \text { PO Box 2075 } \\ & \text { Colombo } \\ & \text { Sri Lanka }\end{array}$

\section{BANGLADESH}

IIMI, Bangladesh Field Operations 56 A, Road 16 (New)

Dhanmandi R.A.

Dhaka 1209

Bangladesh

$\begin{array}{ll}\text { Telephone }: & (880-2) 324128 \\ \text { Telex } & : \text { 642940 ADAB B] } \\ & (\text { Attn:IMM) } \\ \text { Fax } \quad & (880-2) 813095 \\ & (\text { Attn:IIMI) } \\ \text { PO Box }: & \text { PO Box } 7187, \text { Dilkusha } \\ & \text { Dhaka-1000, Bangladesh } \\ \text { E-Mail } \quad & \text { FORD-DHAKA } \\ & (157: \text { CGI241) } \\ & \text { (Attn. IIMI) }\end{array}$

\section{MOROCCO}

IIMI, Morocco Field Operations IIMI c/o SEHA 461, Avenue Hassan II Al Akkati, Rabat

Morocco

$\begin{array}{ll}\text { Telephone : } & (212-7) 691101 \\ \text { Telex } & : \text { MARADER 36705M } \\ & \text { (Quote "IIMI") } \\ \text { Fax } & \text { (212-7) 691101 or } \\ & \text { thro' Backup Services } \\ & 44-491-32002 \\ & : \text { IIMI-RABAT } \\ \text { E-Mail } & \text { (157:CGI064) }\end{array}$

NEPAL

IIMI, Nepal Field Operations PO Box 3975

Kathmandu, Nepal

$$
\begin{aligned}
\text { Telephone : } & 977-1-414376 \text { or } \\
& 411912,419957, \\
& 415535 \text { (Ext.18) } \\
\text { Telex }: & 2321 \text { BASS NP } \\
& \text { (Amn: IIMI) Alt } \\
& \text { \&. Saturdays: } 2660 \\
& \text { GURANS NP } \\
& : \text { 977-1-419956 } \\
\text { Fax } & \text { Alt. } 977-1) 521880 \\
\text { E-Mail } \quad & \text { IIMI-Nepal } \\
& (157: \text { CGI106) }
\end{aligned}
$$

\section{PAKISIAN}

IIMI, Pakistan Division

1-A/B, Danepur Road

GOR I, Lahore

Pakistan

$$
\begin{array}{ll}
\text { Telephone } & :(92-42) 368610,303251 \\
\text { Telex } & : 44926 \text { IIMIP PK } \\
\text { Fax } & :(92-42) 369194 \\
\text { E-Mail } & : \text { IIMI-PAK (157:CGI220) }
\end{array}
$$

\section{PHILIPPINES}

IIMI, Philippines Field Operations 2nd Floor

ICC Bldg, NIA Compound EDSA, Diliman

Quezon City, Metro Manila Philippines

$$
\begin{aligned}
& \text { Telcphone : }(63-2) 99-93-46 \\
& \text { Telex : 40404 GMCR } \\
& \text { (AttnIIIMI) } \\
& \text { Fax } \\
& \text { : (63-2) 99-93-46 }
\end{aligned}
$$

\section{SRI LANKA}

IIMI, Sri Lanka Field Operations 107, Havelock Road, Colombo 5 Sti Lanka

$\begin{array}{ll}\text { Telephone } & :(94-1) 508001 / 7 \\ \text { Telex } & : 22318 \text { or } 22907 \\ & \text { IIMIHQ CF } \\ \text { Fax } & :(94-1) 508008\end{array}$

\section{SUDAN}

IIMI, Sudan Field Operations St. 53 New Extension

House 9/11, PO Box 2976

Khartoum, Sudan

$$
\begin{array}{ll}
\text { Telephone }: & (249-11) 45816,45742 \\
\text { Telex } & : 24088 \text { GUL SD } \\
& 22255 \text { ASIN SD }
\end{array}
$$

IIMI-Sudan, Field Office

PO Box 318, Wad Medani, Sudan

$$
\begin{array}{ll}
\text { Telephone } & : 3148 \text { (Gezira System) } \\
\text { Telex } & : 50013 \text { HRS SD or } \\
& \text { 50009 TXBOWD SD } \\
& \text { (c/o. Mr. Monshid, HRS) }
\end{array}
$$

\section{WEST AFRICA REGIONAL OFFICE}

IIMI, West Africa Regional Office IIMI BP 5373

Ouagadougou (BF), Burkina Faso

$$
\begin{aligned}
\text { Telephone }: & (226) 308489 \\
\text { Telex } & =5381 \text { SAFGRAD BF } \\
& \text { (Attn: IIMI) } \\
\text { Fax } & (226) 31-06-18 \text { or } \\
& \text { ihro' Backup Services } \\
& 44-491-32002 \\
\text { E-Mail } \quad & \text { IIMI-BURKINA } \\
& (10074: \text { CGU033) } \\
& (157: \text { CGI195) }
\end{aligned}
$$

\section{NIGER}

IIMI, Niger Office

IIMI BP 10883, Niamey, Niger

$$
\begin{aligned}
\text { Telephone }: & (227) 73-29-58,(227) \\
& 73-29-73 \\
\text { Telex } & : 5463 \text { NI (Arm. } \\
& \text { Kurt Lonsway) } \\
\text { Fax }: & (227) 73-59-83 \\
\text { E-Mail }: & \text { IIMI-NIGER } \\
& (157: \text { CGI058) }
\end{aligned}
$$

\section{NIGERIA}

IIMI, Nigeria Office clo, ICRISAT-WASIP

Plot 419 Yanyawa Avenue Hotoro GRA Extension PMB 3491, Kano, Nigeria

$$
\begin{array}{ll}
\text { Telex } & \text { : } 77330 \text { or } \\
& 77444 \text { KN BTH } \\
& \text { Attn. P. Pradhan } \\
& \text { Project Leader } \\
& \text { IIMI-ICRISAT } \\
& \text { Program, Kano }
\end{array}
$$

